\title{
Targeting focal adhesion assembly by ethoxyfagaronine prevents lymphoblastic cell adhesion to fibronectin
}

\author{
F. Ouchani ${ }^{\mathrm{a}}$, J. Devy ${ }^{\mathrm{a}, *}$, A. Rusciani ${ }^{\mathrm{a}}$, J.J. Helesbeux ${ }^{\mathrm{b}}$, S. Salesse ${ }^{\mathrm{a}}$, I. Letinois ${ }^{\mathrm{a}}$, D. Gras-Billart ${ }^{\mathrm{a}}$, \\ L. Duca ${ }^{\mathrm{a}}$, O. Duval ${ }^{\mathrm{b}}$, L. Martiny ${ }^{\mathrm{a}}$ and E. Charpentier ${ }^{\mathrm{a}}$ \\ ${ }^{a}$ Université de Reims Champagne Ardenne, CNRS 6237 MEDyC, Laboratoire SiRMa, IFR 53 Interactions \\ Cellules-Microenvironnement, Reims, France \\ ${ }^{\mathrm{b}}$ Université d'Angers, SONAS, UFR Sciences Pharmaceutiques et Ingénierie de la Santé, Angers, France
}

Received: 28 July 2011

Accepted: 6 February 2012

\begin{abstract}
Background: Leukemic cell adhesion to proteins of the bone marrow microenvironment provides signals which control morphology, motility and cell survival. We described herein the ability of ethoxyfagaronine (etxfag), a soluble synthetic derivative of fagaronine, to prevent leukemic cell adhesion to fibronectin peptide (FN/V).

Methods: Phosphorylation of fak and pyk2 were evaluated by immunoblotting. Labelled proteins were localized by confocal microscopy. PI 3-kinase activity was evaluated by in vitro kinase assay.

Results: Subtoxic concentration of etxfag reduced L1210 cell adhesion to FN/V dependently of $\beta 1$ integrin engagement. Etxfag impaired FN-dependent formation of $\beta 1$ clustering without modifying $\beta 1$ expression at the cell membrane. This was accompanied by a decrease of focal adhesion number, a diminution of fak and pyk2 phosphorylation at Tyr-576, Tyr-861 and Tyr-579, respectively leading to their dissociations from $\beta 1$ integrin and inhibition of PI 3-kinase activity. Etxfag also induced a cell retraction accompanied by a redistribution of phosphorylated fak and pyk2 in the perinuclear region and lipid raft relocalization.

Conclusion: Through its anti-adhesive potential, etxfag, combined with conventional cytotoxic drugs could be potentially designed as a new anti-leukemic drug.
\end{abstract}

Keywords: Adhesion, ethoxyfagaronine, integrin, focal adhesion kinases, acute leukemia

\section{Introduction}

Leukemias are defined as uncontrolled proliferation and enhanced invasiveness of hematopoietic cells that fail to differentiate into mature blood cells. Acute lymphoblastic leukemia (ALL) originates from a single lymphoid progenitor and is characterized by an excessive egress of leukemic blasts from bone marrow (BM)

\footnotetext{
*Corresponding author: Jérôme Devy, Université de Reims Champagne Ardenne, UMR CNRS 6237 MEDyC, Laboratoire SiRMa, IFR 53 Interactions Cellules-Microenvironnement, Moulin de la Housse, BP 1039, 51687 Reims, France. Tel.: +33 303269133 49; Fax: +3330326918366; E-mail: jerome.devy@univ-reims.fr.
}

to peripheral blood. Subsequent leukemic cell invasion of extramedullary sites require cell adhesion to extracellular matrix (ECM) proteins, ECM proteolysis, basement membrane crossing and migration into the surrounding tissues [1]. Leukemic cell dissemination can be efficiently reduced by blocking matrix metalloproteinases (MMPs), endopeptidases with proteolytic activity for a large range of ECM components [2-4]. As adhesive properties of leukemic cells are responsible for leukostasis complication, the disruption of adhesion pathways might also be of therapeutic benefit [5]. Hematopoietic cell interactions with BM proteins are largely mediated by integrin adhesion receptors that consist of $\alpha$ and $\beta$ integrin subunits [6]. Among 
these receptors, $\alpha 4 \beta 1$ and $\alpha 5 \beta 1$ constitute receptors for fibronectin $(\mathrm{FN})$, extensively found within the hematopoietic microenvironment [7]. FN proteolysis leads to proteolytic fragments containing a RGD sequence recognized by $\alpha 5 \beta 1$ [8]. Another peptide FN-CH/V corresponding to the sequence WQPPRARI (FN/V) promotes adhesion, spreading and cell migration by direct interaction with $\alpha 4 \beta 1[9,10]$. High levels of $\alpha 4 \beta 1$ are expressed in normal and leukemic progenitors and $\alpha 4 \beta 1$ integrin is a modulator which alters migration and BM localization [11].

Integrin-mediated cell adhesion signaling from outside to inside the cell is mainly coordinated by the focal adhesion kinase (fak) and the proline-rich tyrosine kinase (pyk2). Once activated by phosphorylation, these non-receptor tyrosine kinases serve as docking sites for $\mathrm{SH} 2$ domain containing proteins such as the p85 subunit of the phosphatidylinositol 3-kinase (PI 3-K), Src family kinases and p120 Ras GAP $[12,13]$. In acute myeloid leukemia, fak expression and activity are linked with enhanced blast migration, malignant or metastasic disease and poor prognosis in patients [14]. Pyk2 is highly expressed in hematopoietic and neuronal cells and its overexpression is often correlated with increased metastasis [15-18].

Despite a good cure rate of childhood ALL, many patients still develop serious acute and late complications mainly due to cancer treatment side effects. Moreover, the survival rate of ALL adults remains below $40 \%$ in most studies and treatment outcome is poor among patients who relapse on current front-line ALL regimens. New treatments are still requested to improve the cure rate and the quality of life of ALL patients. Targeting leukemic cell interactions with the surrounding microenvironment and more specifically focal adhesion assembly could represent an innovative and original approach to prevent leukemic cell dissemination. Natural substances and their designed derivatives represent powerful tools in the engineering of new anticancer drugs [19]. Ethoxyfagaronine (etxfag), a hemi-synthetic derivative of fagaronine, exhibits a high DNA binding affinity but a low cytotoxicity in vitro $[20,21]$. We recently reported that etxfag reduces L1210 lymphoblastic cell invasiveness through a down-regulation of plasminogen activators and MT1-MMP expression and activation [22]. We now investigate etxfag effects on L1210 cell adhesion. We describe the ability of etxfag to inhibit cell adhesion to FN/V by disrupting lipid raft organization and preventing $\beta 1$ integrin clustering. This is accompanied by subsequent attenuation of fak and pyk 2 phosphorylation and a decrease of PI 3-kinase activity. All together our results show that etxfag exhibits potent anti-leukemic activity and emphasize its clinical potential in combination with conventional cytotoxic drugs.

\section{Materials and methods}

\subsection{Reagents}

Ethoxyfagaronine (N-methyl-12-ethoxy-2hydroxy-3, 8, 9-trimethoxybenzo[c] phenanthridinium chloride) was provided by Pr Olivier DUVAL (SONAS, Angers). Stock solution of ethoxyfagaronine (etxfag) was prepared at $10^{-2} \mathrm{M}$ in water and stored at $4^{\circ} \mathrm{C}$. All reagents for cell culture were from Gibco BRL (Invitrogen, CergyPontoise, France). The anti-mouse $\beta 1$ integrin (Sc-6622; Sc-8978), anti-fak (Sc-557), anti-pyk2 (Sc-1514 and anti- $\beta$ actin (Sc-1616) and anti-vinculin (Sc5573) antibodies were obtained from Santa Cruz Biotechnology Inc (Tebu, Le Perray en Yvelines, France). Anti-phosphotyrosine-576-fak was from USB biological (Euromedex, Souffelweyersheim, France), anti-phosphotyrosine-861-fak (\#2153-1) was from Epitomics (Euromedex, Souffelweyersheim, France). Anti-phosphotyrosine-579-pyk2 was from Biosource Invitrogen (Fisher Scientific, Illkirch, France). Peroxidase-conjugated anti-rabbit antibody (\#7074) was from Cell Signaling Technology (Ozyme, Saint-Quentin-en Yvelines Cedex France). LY303511 was from Calbiochem (distributed by VWR International, Strasbourg, France). LY294002 was purchased from Cell Signaling Technology Inc. (distributed by Ozyme, Saint-Quentin en Yvelines, France). Alexafluor 568 phallöidin, Alexafluor 488, Alexafluor 488 conjugated cholera toxin subunit $\mathrm{B}(\mathrm{CTxB})$ and Pro long mounting medium with DAPI were from Invitrogen (Fisher Scientific, Illkirch, France). Polyclonal anti-CD29 antibodies were from Santa Cruz (Santa Cruz,CA, USA). All antibodies were assessed for mouse cross-reactivity. Bicinchonic acid protein assay and ImmunoPure ${ }^{\circledR}$ immobilized streptavidin on agarose beads and EZ-Link ${ }^{\mathrm{TM}}$ Sulfo-NHS-LC-Biotin were from Pierce Chemical (Interchim, Montluçon, France). Extract-all was from Eurobio (Eurobio, Les Ulis, France). Verso SYBR Green 2-Step QRT-PCR Rox kit and Absolute SYBR Green Rox mix were from Thermo Electron (Thermo Electron, Courtaboeuf, 
France). The prestained protein ladder (\#SM0671) used for zymography was from Fermentas (Fermentas, St Rémy Les Chevreuse, France). Anti-peroxidaseconjugated anti-goat antibody, methyl- $\beta$-cyclodextrin (MBCD), fibronectin petide (F-3667), Phosphate Buffered Saline and all others reagents were from Sigma (Saint Quentin Fallavier, France). The proteinG-agarose beads were from Boehringer (Boehringer Mannheim, Indianapolis, IN, USA).

\subsection{Cell treatment}

To study the effect of etxfag on cell adhesion, $1 \times 10^{-7}$ L1210 cells were incubated for $24 \mathrm{~h}$ at $37^{\circ} \mathrm{C}$ in RPMI-1640-Glutamax containing $10 \%(\mathrm{v} / \mathrm{v})$ FBS and $1 \times 10^{-7} \mathrm{M}$ etxfag, then washed twice with serum free RPMI-1640-Glutamax. To study the effect of $\mathrm{Mg}^{2+}$ and EDTA on adhesion, L1210 cells were incubated for $30 \mathrm{~min}$ under gentle stirring in serum-free RPMI-1640-Glutamax supplemented with $5 \mathrm{mMMg}^{2+}$ or $5 \mathrm{mM}$ EDTA and maintained in this medium throughout the experiment. Aliquots $\left(25 \times 10^{4}\right.$ cells $)$ were plated on 24 -well plates for adhesion assays.

\subsection{Adhesion assay}

24-well tissue culture plates were coated with $200 \mu \mathrm{L} \mathrm{FN} / \mathrm{V}(50 \mu \mathrm{g} / \mathrm{mL}$ PBS $)$ overnight at $4^{\circ} \mathrm{C}$, blocked with $1 \%(\mathrm{w} / \mathrm{v})$ heat-denatured BSA for $1 \mathrm{~h}$ at $37^{\circ} \mathrm{C}$ and washed once with PBS. $25 \times 10^{4}$ cells/800 $\mu \mathrm{L}$ RPMI 1640-Glutamax were added in each well and incubated at $37^{\circ} \mathrm{C}$ from 0 to $2 \mathrm{~h}$. After the incubation period, non-adherent cells were discarded. Adherent cells were rinsed thrice with heated medium $\left(37^{\circ} \mathrm{C}\right)$, fixed for $10 \mathrm{~min}$ with $4 \%(\mathrm{w} / \mathrm{v})$ paraformaldehyde in PBS, stained for $10 \mathrm{~min}$ with $0.5 \%(\mathrm{w} / \mathrm{v})$ violet crystal (20/80: methanol/water), washed thrice with PBS. Violet crystal was solubilized with $100 \mu \mathrm{L}$ DMSO and absorbance was recorded at $600 \mathrm{~nm}$ and was strictly correlated to the cell number [23].

\subsection{Western blotting}

$35 \times 10^{4}$ cells $/ \mathrm{mL}$ were plated on tissue culture plates $\left(25 \mathrm{~cm}^{2}\right)$ coated with FN/V $(50 \mu \mathrm{g} / \mathrm{mL})$ or BSA $1 \%(\mathrm{w} / \mathrm{v})$ and incubated for $2 \mathrm{~h}$ at $37^{\circ} \mathrm{C}$. The non-adherent cells were discarded and the plates rinsed thrice with ice-cold PBS containing $50 \mu \mathrm{M}$
$\mathrm{Na}_{3} \mathrm{VO}_{4}$. The adherent cells were lysed in $200 \mu \mathrm{L}$ lysis buffer and cell lysates were analysed as described [22].

\subsection{Immunoprecipitation}

Whole cell lysates were precleared with $30 \mu \mathrm{L}$ protein-G-agarose for $1 \mathrm{~h}$ at $4^{\circ} \mathrm{C}$ on a rotating platform. The supernatant was then transferred in a tube containing $2 \mu \mathrm{g}$ polyclonal anti-CD29 antibodies and rotated overnight at $4{ }^{\circ} \mathrm{C}$. $35 \mu \mathrm{L}$ protein-G-agarose beads were added to immune complexes and gently rotated for $1 \mathrm{~h}$. Beads were then washed thrice with PBS containing $1 \%(\mathrm{v} / \mathrm{v}) \mathrm{NP}-40$ and bound material was recovered by boiling in Laemmli buffer for $5 \mathrm{~min}$.

\subsection{PI 3-kinase assay}

Following etxfag incubation and adhesion to FN/V, cells were lysed as described above. The proteins were immunoprecipitated with $2 \mu \mathrm{g}$ anti-p85 antibodies and PI 3-kinase assays were performed as described previously [24]. Quantification of PI phosphorylation detected by autoradiography was performed by densitometry and subsequent analysis using the program Image Quant (Molecular Dynamics).

\subsection{Cell surface protein biotinylation}

Cells were washed with ice-cold PBS containing $20 \mu \mathrm{M} \mathrm{Na}{ }_{3} \mathrm{VO}_{4}$ and incubated with $0.5 \mathrm{mg} / \mathrm{mL}$ EZ-Link ${ }^{\mathrm{TM}}$ Sulfo-NHS-LC-Biotin, a membrane impermeable biotinylation reagent, in $\mathrm{PBS}$ at $4^{\circ} \mathrm{C}$ for $30 \mathrm{~min}$. Cell surface proteins were separated as described previously and analysed by SDS-PAGE followed by western blotting [22].

\subsection{RNA isolation, RT-PCR and real-time PCR}

Cells $\left(35 \times 10^{4}\right.$ cells $\left./ \mathrm{mL}\right)$ were plated on tissue culture plates coated with FN/V $(50 \mu \mathrm{g} / \mathrm{mL})$ and incubated for $2 \mathrm{~h}$ at $37^{\circ} \mathrm{C}$. Non adherent cells were discarded and the plates rinsed thrice with PBS. Adherent cells were scrapped in the same buffer and centrifuged $\left(800 \mathrm{~g}, 5 \mathrm{~min}, 4^{\circ} \mathrm{C}\right)$. Total RNAs were extracted using TRI Reagent. 500 nanograms were subjected to reverse transcription using Verso transcriptase (Thermo Electron, Courtaboeuf, France). Primers for mouse $\beta 1, \beta 2$ and $\beta 3$ integrin subunits and $\beta$ actin, RPS26 were synthesized by Eurogentec (France) and their sequences 
Table 1

Primer sequences used for RT-PCR studies

\begin{tabular}{lll}
\hline Genes & Pnmer sequence forward $5^{\prime}-3^{\prime}$ & Primer sequence reverse 5'-3' \\
\hline$\beta 1$ integrin & CAA-TTG-TAG-CAG-GCG-TGG-TTG & GAC-CAC-AGT-TGT-CAC-GGC-ACT \\
$\beta 2$ integrin & AGC-CCA-TCT-TTG-CGG-TGA-C & TGC-ACC-ACG-TTG-CTG-GAG-T \\
$\beta 3$ integrin & AAC-AAC-GAG-GTT-ATC-CCG-GG & CGG-TGA-GGC-TGT-CCT-TAA-AG \\
$\beta$-Actin & CCC-TAA-GGC-CAA-CCG-TGA-A & ACA-GTG-TGG-GTG-ACC-CCG-T \\
RPS26 & TAG-AAG-CCG-CTG-CTG-TCA-GG & GGC-ACA-GCT-CAC-GCA-ATA-AT \\
\hline
\end{tabular}

were presented in Table 1. Numbers of cycles were adjusted to ensure that amplifications were in a linear range. Real-time PCR was performed as described previously [22] to assess expression of $\beta 1$ integrin genes. The entire experiment from RNA extraction to realtime PCR steps was repeated four times with different sets of samples.

\subsection{Cellular extraction of total lipids and GMI titration}

Cell pellets obtained from L1210 cells $(400 \mathrm{~g}$, $10 \mathrm{~min}, 4^{\circ} \mathrm{C}$ ) treated in the presence or in the absence of $1 \times 10^{-7} \mathrm{M}$ etxfag for $24 \mathrm{~h}$ were suspended in $600 \mu \mathrm{L}$ of distilled water. Protein concentrations were determined by Bradford assay (Bio-Rad, Marne la Vallée, France). Equal amounts of proteins were mixed with $2.4 \mathrm{~mL}$ of a chloroform/methanol $(2: 1(\mathrm{v} / \mathrm{v})) \mathrm{mix}-$ ture and centrifuged $\left(5000 \mathrm{~g}, 10 \mathrm{~min}, 4^{\circ} \mathrm{C}\right)$. Aqueous and organic phases were collected and evaporated under nitrogen and mixed with $300 \mu \mathrm{L}$ of chloroform $/$ methanol $(1: 5(\mathrm{v} / \mathrm{v}))$. A nitrocellulose membrane was then placed in a 96-well plate system using Bio-dot microfiltration system (Bio-rad). Each well was incubated with $100 \mu \mathrm{L}$ of aqueous or organic phases from lipid extraction during $30 \mathrm{~min}$. Wells were washed twice with $100 \mu \mathrm{L}$ TBS $\mathrm{pH} 8$ and saturated with $50 \mu \mathrm{L}$ BSA $6 \mathrm{mg} / \mathrm{mL}$ during $1 \mathrm{~h}$. After 2 washes with $100 \mu \mathrm{L}$ TBS $\mathrm{pH} 8$, wells were incubated with $50 \mu \mathrm{L}$ cholera toxin B subunit coupled Alexa Fluor 488 (dilution $1 / 1000$ in TBS $\mathrm{pH} 8$ ) during $45 \mathrm{~min}$. After 3 washes with $100 \mu \mathrm{L}$ TBS $\mathrm{pH} 8$, the nitrocellulose membrane was revealed with a microplate spectrofluorimeter Infinite ${ }^{\circledR}$ F200 Pro (TECAN, Lyon, France).

\subsection{Immunofluorescence}

Cells $\left(25 \times 10^{4}\right)$ were plated on glass-slides, incubated for $2 \mathrm{~h}$ à $37^{\circ} \mathrm{C}$ and fixed with $4 \%$ (v/v) paraformaldehyde for $5-10 \mathrm{~min}$ at $4^{\circ} \mathrm{C}$. The slides were washed with PBS and saturated in PBS with
$2 \%(\mathrm{w} / \mathrm{v}) \mathrm{BSA}$ for $30 \mathrm{~min}$. Cells were then incubated overnight at $4{ }^{\circ} \mathrm{C}$ with anti $\beta 1$-integrin, anti-fak or anti-vinculin antibody and with antibody against phosphorylated-Y576-fak, Y861-fak, Y579-pyk2. Slides were washed five times in PBS and incubated for $1 \mathrm{~h}$ with Alexafluor 488-conjugated secondary antibody diluted $1 / 1000$ in PBS with $2 \%$ (w/v) BSA. To visualize $\mathrm{F}$-actin distribution, slides were incubated for 45 min with Alexafluor-568-conjugated phalloidin diluted 1/100 in PBS with 2\% (w/v) BSA. Cells were then washed with PBS. Conditions without the first antibody were used as control. Nuclei were counterstained with DAPI. Immunofluorescence-labeled cell preparations were analysed using a Zeiss LSM 710 confocal laser scanning microscope with the $63 \mathrm{X}$ oil-immersion objective zoom $3 \mathrm{X}$ and Zeiss operating system (Carl Zeiss MicroImaging GmbH, Deutschland). Acquisitions were performed by exciting Alexafluor 488, Alexafluor 568 and DAPI dye with Argon laser, HeNe laser and chameleon IR laser tuned at $730 \mathrm{~nm}$ respectively. Emitted fluorescence was detected through the appropriate wavelength window. Twenty images were captured with a $0.25 \mu \mathrm{m}$ z-step.

\subsection{Images post-processing}

Surfacic representations were realized using AMIRA (v5.2) software (Visage Imagin ${ }^{\circledR}$, Berlin, Germany). To compare cell labeling, a same threshold was applied for each channel of untreated versus etxfag-treated cells. For colocalization studies, a multichannel field module was used, followed by a correlation plot treatment (sub-ranges values 15-255, gamma 0.5). A surfacic representation of the correlation plot was realized using the same threshold for untreated versus etxfag-treated cells.

\subsection{Statistical analysis}

Values are means \pm SEM of triplicate determinations or means $\pm \mathrm{SD}$ of duplicate determinations. The 
statistical significance of differences was calculated using Student's test. $P$ values referring to corresponding controls are indicated in Figure legends. $* P<0.05$; $* * P<0.01, * * * P<0.001, \mathrm{NS}=$ non significant.

\section{Results}

\subsection{Ethoxyfagaronine prevented L1210 cell adhesion to fibronectin via alteration of $\beta 1$ integrin clustering}

As cell adhesion to BM proteins regulates leukemic cell properties, we assessed adhesion of L1210 cells to fibronectin-derived peptide FN/V, described for its ability to strongly induce hematopoietic cell adhesion through interaction with VLA-4 receptor [9]. L1210 cell line is usually used in comparative in vitro tests to evaluate the anti-leukemic potential of new drugs. FN/V peptide significantly enhanced in a timedependent manner L1210 cell adhesion as compared to BSA controls (Fig. 1a). L1210 cell adhesion to FN/V was reduced with $5 \mathrm{mM}$ EDTA and enhanced with $5 \mathrm{mM} \mathrm{Mg}^{2+}$ suggesting that divalent cations could be involved in L1210 cell adhesion to FN/V (Fig. 1b). Integrins constitute one of the major classes of adhesion molecules and particularly, $\beta 1$ integrin is one of the cation divalent-dependent FN/V receptors [9]. L1210 cells mostly express $\beta 1$ subunit (RT-PCR and western blot analyses; Fig. 1c) and the anti- $\beta 1$ blocking antibody $(10 \mu \mathrm{g} / \mathrm{mL})$ significantly reduced $(65 \%)$ their ability to adhere to FN/V (Fig. 1d). Ethoxyfagaronine (etxfag) used at a subtoxic concentration of $1 \times 10^{-7} \mathrm{M}$ decreased the number of adhered cells to FN/V but had no effect on cell adhesion to BSA (Fig. 2a). Surprisingly, etxfag affected neither expression of $\beta 1$ mRNA (qRT-PCR analyses, Fig. $2 b$ ) nor $\beta 1$ protein expression in L1210 cells (western blot, Fig. 2c). To explain these results, we hypothesized that etxfag could alter $\beta 1$ integrin localization at the cell membrane with consequences on $\beta 1$ clustering and signaling. To address this point, cell surface proteins were biotinylated with sulfo-NHS-biotin and treated with etxfag. Western blot analyses of biotinylated proteins rules out this hypothesis (Fig. 2d).

Once bound to ECM proteins, integrins cluster in the plane of cell membrane and associate with a cytoskeletal and signaling complex that promotes actin filament assembly. This prompted us to explore $\beta 1$ integrin distribution and actin localization in L1210 cells treated with etxfag. Differential interferential contrast microscopy and confocal fluorescent imaging followed by surface reconstruction post-processing of $\beta 1$ integrin and actin distribution showed that L1210 cells spread when adhered to FN/V (Fig. 3 left row and Fig. 4 left row). This spreading was characterized by well-organized cortex fibers, membrane ruffles, leading edge lamellipodia (Fig. 3 left row middle panel) and $\beta 1$ integrin clustering at the cell periphery (Figs. 3 and 4 , left row, upper panel, white arrows). Moreover, a strong colocalization of $\beta 1$ integrin clusters and F-actin indicated developed cytoskeleton structures (Fig. 3, left row, bottom panel, white arrows). Imaging of vinculin (a cytoskeletal protein involved in the linkage of integrin to actin) by confocal microscopy showed localization in the extended cytoskeleton structures (Fig. 4, left row, middle panel). Moreover, $\beta 1$ and fak co-localization demonstrated numerous sites corresponding to focal adhesion complexes (Fig. 4, left row bottom panel). Differential interferential contrast microscopy and confocal fluorescent imaging showed that etxfag induced cell rounding and retraction from the substratum (Figs. 3 and 4, right row). Etxfag also inhibited the FN/V-dependent $\beta 1$ integrin clustering (Figs. 3 and 4, right row, upper panel) and prevented F-actin network extensions, membrane ruffles and lamellipodia (Fig. 3 right row, middle panel). Colocalization experiments of F-actin with $\beta 1$ integrin supported these results (Fig. 3, right row, bottom panel) and demonstrated a diffuse distribution of $\beta 1$ integrin and F-actin. To go deeper in etxfag molecular mechanisms, localization of vinculin was evaluated and appeared at the perinuclear region (Fig. 4, right row, middle panel). These results are also reinforced by the estimation of $\beta 1$ and vinculin co-localization (Fig. 4, left row, bottom panel) and show clearly that etxfag induced a decreasing of these focal adhesion complexes. Interestingly, the results obtained with fak and vinculin others partners of focal adhesion complexes are identical to those obtained with $\beta 1$ and vinculin (supplementary Figure 1).

\subsection{Ethoxyfagaronine prevented phosphorylated fak and pyk 2 association with $\beta 1$ integrin}

We then focused on downstream signaling of $\beta 1$ integrin, particularly on fak and pyk2 kinases. In FN-adhered L1210 cells, fak was phosphorylated on Tyr-576 (P(576)fak) (supplementary Figure 2a) and Tyr-861 (P(861)fak) (Fig. 5a) and associated with $\beta 1$ 
(a)

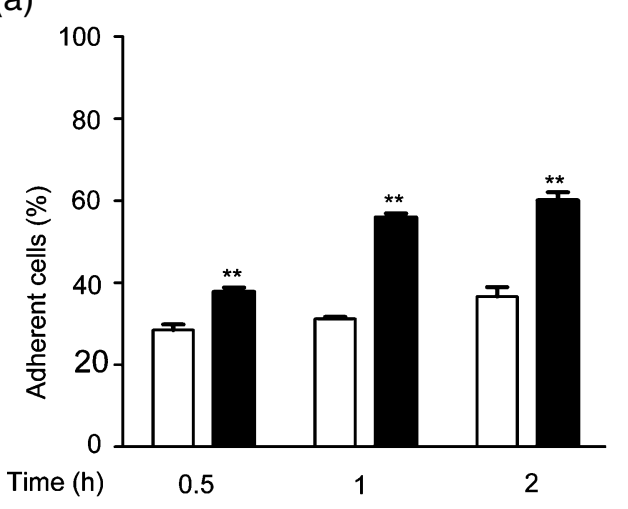

(c)



IB

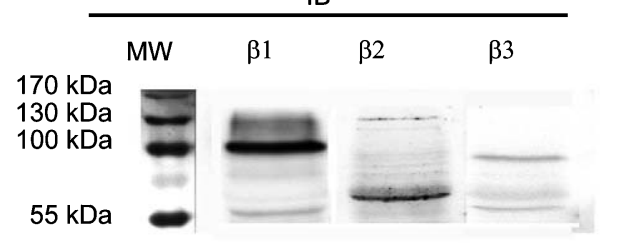

(b)

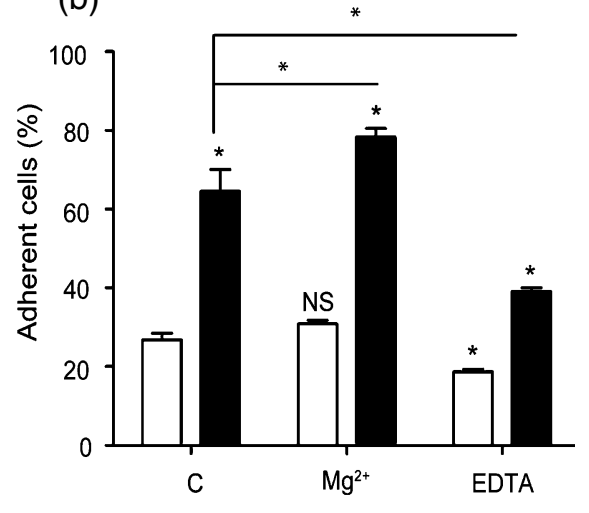

(d)

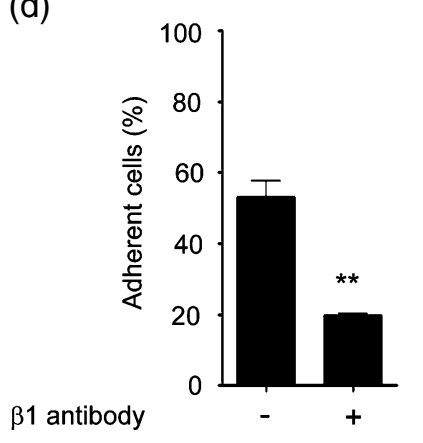

$\beta$ actin

Fig. 1. L1210 cell adhesion to FN/V peptide is mediated by $\beta 1$ integrin. a) $25 \times 10^{4} \mathrm{~L} 1210$ cells were seeded on $1 \%$ BSA ( $\square$ ) or $5 \mu \mathrm{g} / \mathrm{cm}^{2}$ FN/V peptide ( $\mathbf{\square})$ from 0 to $2 \mathrm{~h}$. b) $25 \times 10^{4} \mathrm{~L} 1210$ cells were seeded on $1 \%$ BSA ( $\square$ ) or $5 \mu \mathrm{g} / \mathrm{cm}^{2} \mathrm{FN} / \mathrm{V}$ peptide ( $\left.\mathbf{\square}\right)$ for $2 \mathrm{~h}$ in the presence of $5 \mathrm{mM} \mathrm{Mg}^{2+}$ or $5 \mathrm{mM}$ EDTA. After the incubation period, non-adherent cells were discarded and the percentage of adherent cells was determined by violet crystal staining. Absorbance was recorded at $600 \mathrm{~nm}$. Results are means \pm SEM of three independent experiments. $* P<0.05$; $* * P<0.01$ compared to cells adhered to BSA. NS = non significant. c) mRNA extracted from $3 \times 10^{6}$ L1210 cells were submitted to RT-PCR and a representative electrophoretic pattern of amplification products related to $\beta 1, \beta 2$ and $\beta 3$ integrin subunits was shown. Whole cell extracts were analysed by $10 \%$ SDS-PAGE followed by western blotting using monoclonal anti- $\beta 1, \beta 2$ or $\beta 3$ antibodies. d) $25 \times 10^{4}$ L1210 cells treated with $10 \mu \mathrm{g} / \mathrm{mL} \beta 1$ blocking antibody for $30 \mathrm{~min}$ were seeded on $5 \mu \mathrm{g} / \mathrm{cm}^{2} \mathrm{FN} / \mathrm{V}$ peptide for $2 \mathrm{~h}$. Cell adhesion was evaluated as described in part a. $* * P<0.01$ compared to control isotype antibody $(10 \mu \mathrm{g} / \mathrm{mL})$.

integrin (Fig. 5b and S2b). Moreover, phosphorylated fak was localized at the polarized-cell periphery (Fig. $5 \mathrm{c}$, left row, upper and middle panel). Colocalization studies between $\mathrm{P}(861)$ fak and F-actin and between $\mathrm{P}(576)$ fak and F-actin showed numerous clusters at the periphery of the spread cells (Fig. 5c and S2c, left row, bottom panel, white arrows). Etxfag did not alter fak expression (Fig. 5a and S2a) but attenuated by $40 \%$ fak phosphorylation on Tyr-576 (S2a) and Tyr-861 (Fig. 5a). $\beta 1$ integrin immunoprecipitation showed that etxfag did not alter fak association with $\beta 1$ but decreased the level of phosphorylated fak associated with $\beta 1$, confirming the activity of etxfag on fak phosphorylation only (supplementary Figure $2 \mathrm{~b}$ and Fig. 5b). Confocal experiments revealed that etxfaginduced cell retraction characterized by a reduced actin cortex and a decrease of focal adhesions (Fig. 5c and S2c, right row, upper and middle panels). Along this line, colocalization experiments demonstrated a diffuse repartition of $\mathrm{P}(861)$ fak and F-actin (Fig. 5c and S2c, right row, bottom panel) in L1210 cells treated with etxfag. 
a

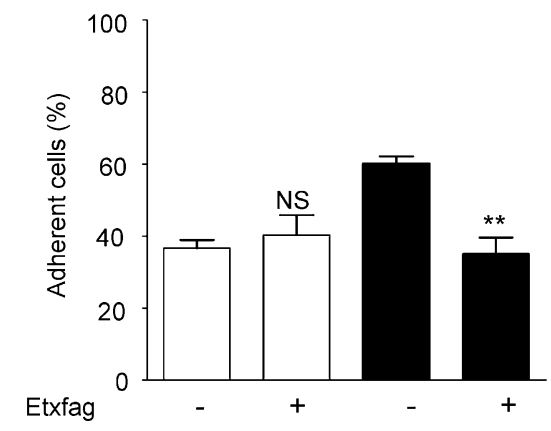

C

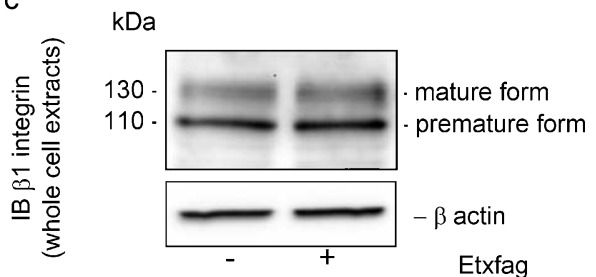

b

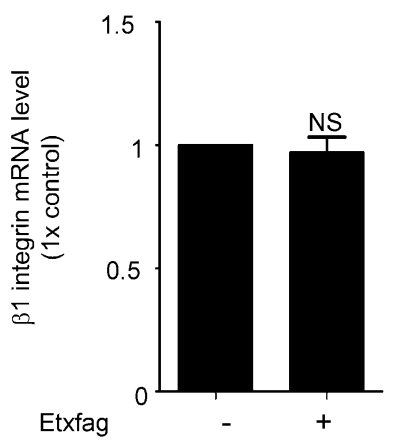

d

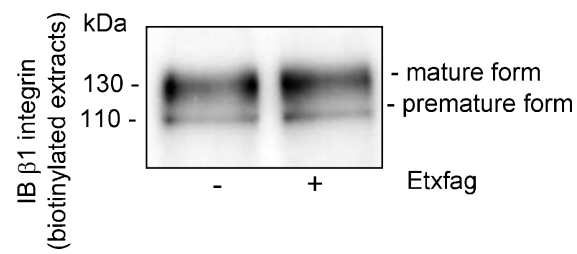

Fig. 2. Etxfag inhibits L1210 cell adhesion to FN/V peptide. a) $25 \times 10^{4} \mathrm{~L} 1210$ cells treated or not with $1 \times 10^{-7} \mathrm{M}$ etxfag for $24 \mathrm{~h}$ were seeded on $1 \%$ BSA $(\square)$ or $5 \mu \mathrm{g} / \mathrm{cm}^{2}$ FN/V peptide $(\square)$ for $2 \mathrm{~h}$. Cell adhesion was evaluated as described in Fig. 1a. $* * P<0.01$ versus to untreated cells. $\mathrm{NS}=$ non significative. b) $\beta 1$ integrin transcript levels were analysed by qRT-PCR as described in section 2 . Error bars represent the SEM for the average fold change of at least three independent replicates. NS = non significative. c) Whole cell extracts obtained from L1210 cells treated or not with $1 \times 10^{-7} \mathrm{M}$ etxfag for $24 \mathrm{~h}$ were analysed by $10 \%$ SDS-PAGE followed by western blotting using anti- $\beta 1$ integrin antibody. A representative blot of three independent experiments was shown. d) L1210 cells were biotinylated and treated or not with $1 \times 10^{-7} \mathrm{M}$ etxfag for $24 \mathrm{~h}$. Biotinylated proteins were analysed by $10 \%$ SDS-PAGE followed by western blotting using monoclonal anti- $\beta 1$ antibody. A representative blot of three independent experiments is shown.

In FN/V-adhered cells, pyk2 was also phosphorylated and co-immunoprecipitated with $\beta 1$ (Fig. 6a and b). As for P-fak, P(579)pyk2 localized at the polarized cell periphery (Fig. 6c, left row, upper and middle panels). Colocalization studies between $\mathrm{P}(579)$ pyk2 and F-actin showed numerous clusters at the spread cell periphery (Fig. 6c, left row, bottom panel, white arrows). Etxfag reduced by $45 \%$ pyk 2 phosphorylation on tyr 579 as well as association with $\beta 1$ integrin (Fig. 6a and b). Moreover, P(579)pyk2 was redistributed in the perinuclear region (Fig. 6c, right row, upper and middle panels) and colocalization evaluation demonstrated a diffuse repartition between $\mathrm{P}(579)$ pyk2 and F-actin (Fig. 6c, right row, bottom panel).

\subsection{Ethoxyfagaronine decreased PI 3-kinase activity}

Since phosphorylated fak leads to the recruitment and subsequent activation of $\mathrm{SH} 2$ domain-containing proteins, activity of PI 3-kinase was evaluated in FN/V-adhered cells. Autoradiographic analyses of phosphorylated PI (PIP) showed that PI 3-kinase activity was lowered by $30 \%$ upon etxfag treatment (Fig. 7a). PI 3-kinase activity was partially blocked by $20 \mu$ M LY294002, a highly specific inhibitor but not by $25 \mu \mathrm{MLY} 303511$, the cell-permeable negative control for LY294002 [25]. Moreover, $20 \mu$ M LY294002 significantly reduced L1210 cell adhesion (Fig. 7b) confirming that L1210 cell adhesion to FN/V involved PI 3-kinase activity.

\subsection{Ethoxyfagaronine relocalized lipid rafts}

Integrin-mediated signaling is dynamically modulated by lipid rafts, membrane microdomains enriched in cholesterol and glycosphingolipid such as ganglioside GM1. To investigate lipid raft involvement in L1210 cell adhesion to FN/V, cells were labelled with FITC-coupled cholera toxin subunit that binds GM1 and visualized by confocal microscopy. In FN/V-adhered L1210 cells, lipid rafts appeared as large patches (Fig. 8a, left row, upper panel). Methyl- $\beta$ cyclodextrin $(\mathrm{M} \beta C D)$ that sequesters cholesterol from cell membranes, induced lipid raft disruption (Fig. 8a, 

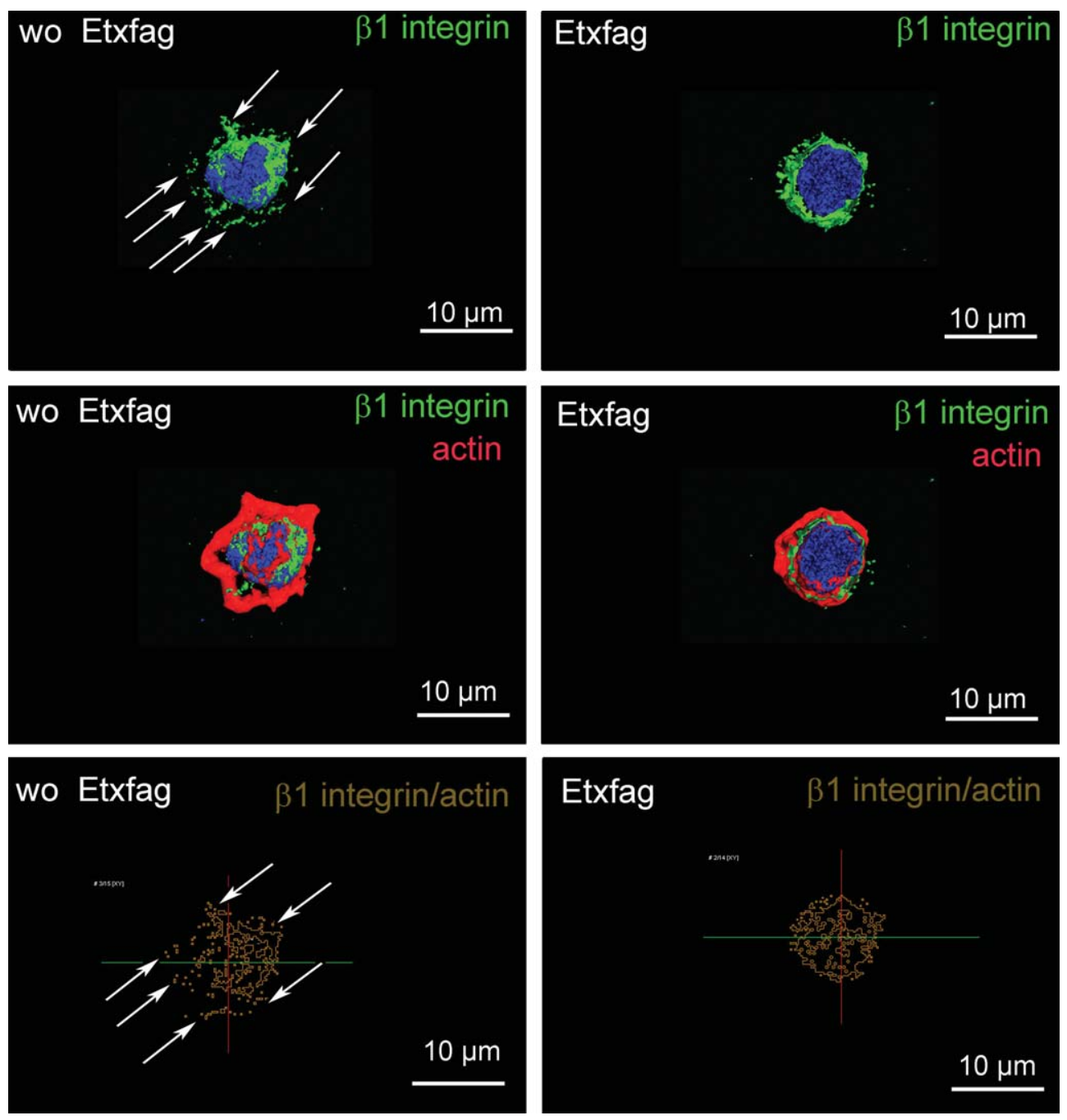

Fig. 3. Etxfag alters $\beta 1$ integrin clustering and actin cytoskeleton expansion in L1210 cells. L1210 cells treated or not with $1 \times 10^{-7} \mathrm{M}$ etxfag during $24 \mathrm{~h}$ were seeded on FN/V-coated glass culture slides in serum-free medium for $2 \mathrm{~h}$. Cells were fixed with $4 \%$ paraformaldehyde then incubated with anti- $\beta 1$ primary antibody $(1: 100)$ and labelled with secondary antibody linked to Alexafluor 488 (green). Cells were also incubated with Alexafluor 568-conjugated phalloidin (red) to visualize F-actin distribution. Emitted fluorescence was detected through the appropriate wavelength window. Twenty images were captured with a $0.25 \mu \mathrm{m}$ z-step. Surfacic reconstructions were realized from L1210 cells treated with or without etxfag (right and left row, respectively). Upper panels represent $\beta 1$ integrin labelling, middle panels represent $\beta 1$ integrin+F-actin labelling and bottom panels represent colocalization of $\beta 1$ integrin and F-actin (gold). A representative image of three independent experiments was shown.

right row, upper panel). When used at $10 \mathrm{mM}$, a non cytotoxic dose for L1210 cells, M $\beta$ CD decreased by $90 \%$ the number of cells adhering to FN/V (Fig. 8a, right row, bottom panel versus left row, bottom panels). As integrin signaling could be linked to lipid raft localization, confocal microscopy experiments were performed and showed that $\beta 1$ integrin colocalized with GM1 at numerous sites (Fig. 8b, right row, upper panel, white arrows). Interestingly, etxfag induced relocalization of GM1 to the cytoplasm (Fig. 8b, left row, bottom panel versus left upper panel). Analysis of total GM1 cellular content showed that Etxfag did not modulate the level of this lipid raft component. These results reinforced the data presented above suggesting relocalization of lipid rafts without modulation of their content (Fig. 8c). Importantly, despite relocalization of lipid rafts, $\beta 1$ integrin residency at the plasma membrane was not modified (Fig. 3). 

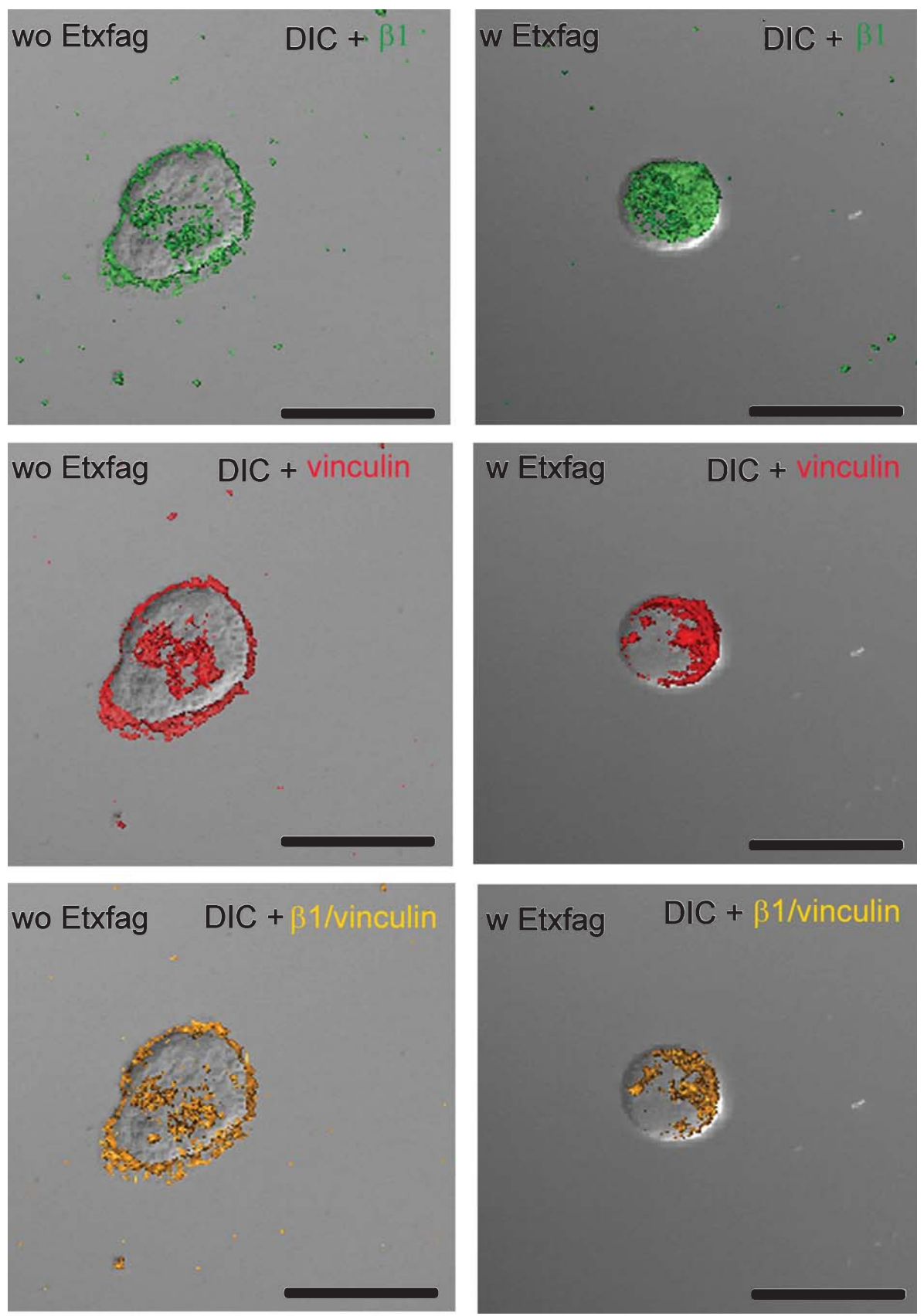

Fig. 4. Etxfag alters the number of focal adhesion complexes in L1210 cells. L1210 cells treated or not with $1 \times 10^{-7} \mathrm{M}$ etxfag during $24 \mathrm{~h}$ were seeded to FN/V-coated glass culture slides in serum-free medium for $2 \mathrm{~h}$. Cells were fixed with $4 \%$ paraformaldehyde then incubated with anti- $\beta 1$ primary antibody $(1: 100)$ and labelled with secondary antibody linked to Alexafluor 488 (green). Cells were also incubated with anti-vinculin primary antibody $(1: 100)$ and labelled with secondary antibody linked to Alexafluor 568-(red). Emitted fluorescence was detected through the appropriate wavelength window. Twenty images were captured with a $0.25 \mu \mathrm{m} \mathrm{z}$-step. Surfacic reconstructions were realized from L1210 cells treated with or without etxfag (right and left row, respectively). Differential interferential contrast imaging of L1210 cells treated or not by etxfag was proceeded (right and left row, upper panel). Upper panels represent $\beta 1$ integrin labelling (green), middle panels represent vinculin labelling (red) and bottom panels represent colocalization between $\beta 1$ integrin and vinculin (gold). A representative image of three independent experiments is shown. Scale bar: $10 \mu \mathrm{m}$. 
a
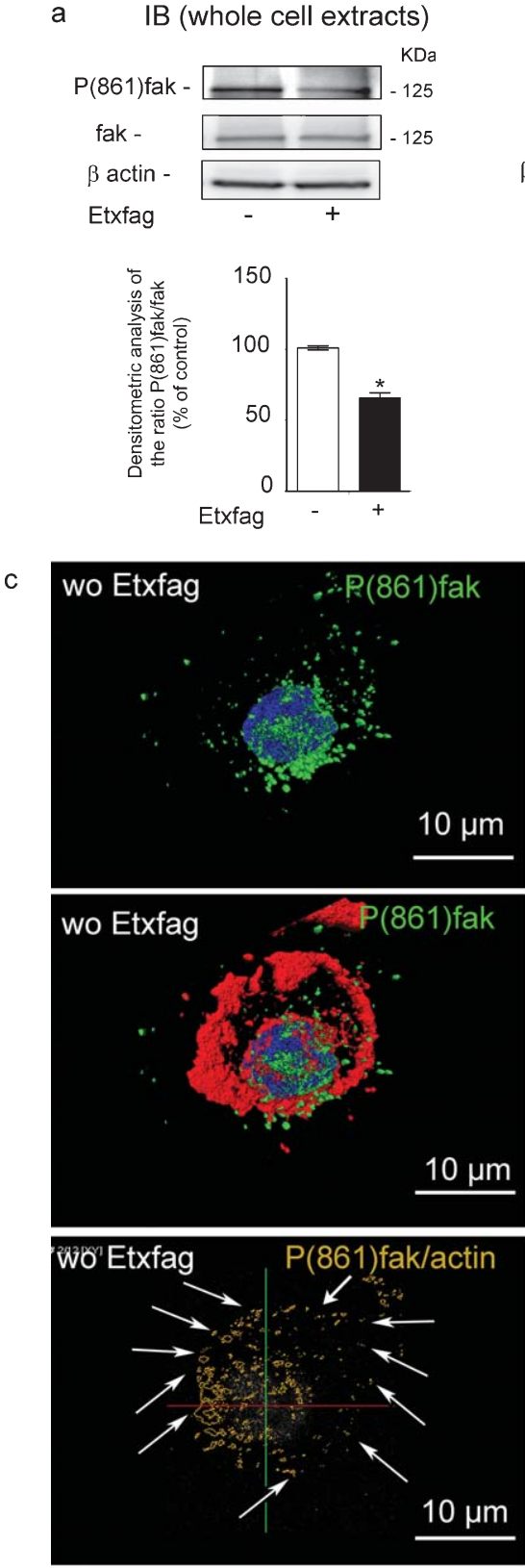
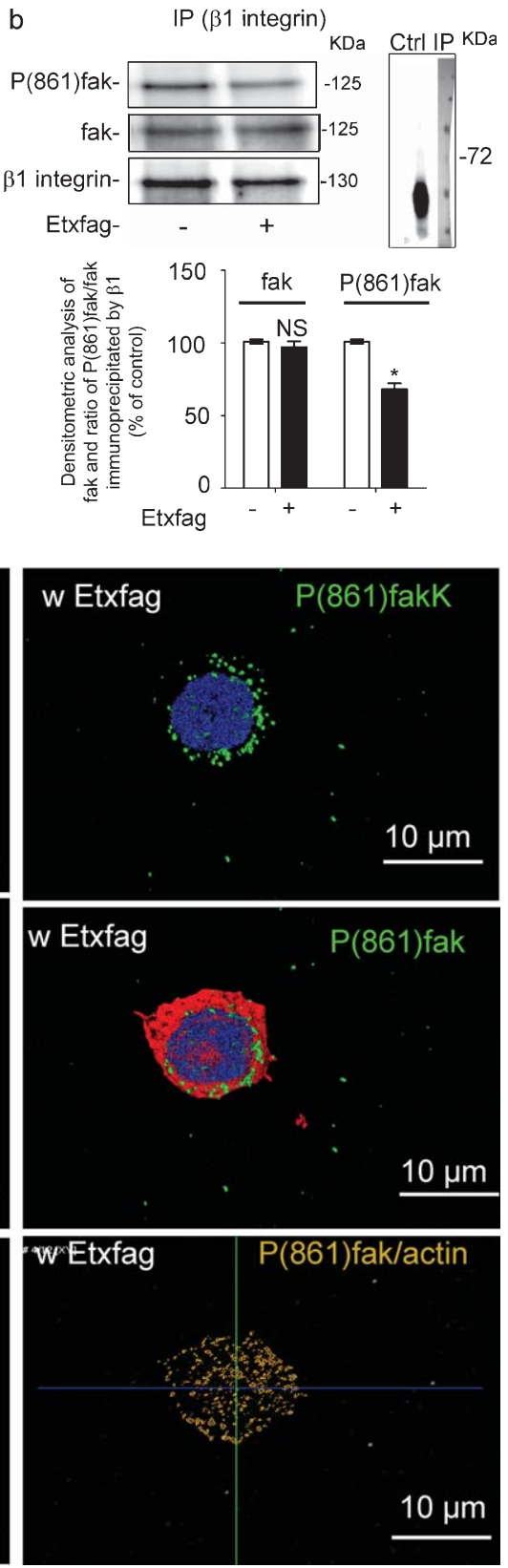

Fig. 5. Etxfag prevents fak phosphorylation on Tyr 861. a) Whole cell lysates prepared from L1210 cells treated or not with $1 \times 10^{-7} \mathrm{M}$ etxfag during $24 \mathrm{~h}$ were subjected to immunoblotting with anti-phosphorylated-Y861 fak and fak. A representative blot of three independent experiments was shown. Graph represents the densitometric analysis of the ratio $\mathrm{P}(861)$ fak/fak in control ( $\square)$ and treated $(\mathbf{\square})$ cells $* P<0.05$. b) Cell lysates prepared from L1210 cells treated or not with $1 \times 10^{-7} \mathrm{M}$ etxfag during $24 \mathrm{~h}$ were immunoprecipitated with anti- $\beta 1$ antibody and immunoblotted with anti-phosphorylated-Y861-fak and fak. Non specific IgGs were used as negative controls of immunoprecipitation (windows). A representative blot of three independent experiments was shown. Graph represents the densitometric analysis of the ratio $\mathrm{P}(861)$ fak/fak in control $(\square)$ and treated ( $\square$ ) cells. c) L1210 cells treated or not with $1 \times 10^{-7} \mathrm{M}$ etxfag for $24 \mathrm{~h}$ were seeded to FN/V for $2 \mathrm{~h}$. Cells were fixed with paraformaldehyde $4 \%$ and permeabilized with $0.1 \%$ Triton X-100. Blue color represents nuclear staining with DAPI. Cells were labelled with anti-phosphorylated-Y861-fak and then with a secondary antibody linked to Alexafluor 488 (green). Cells were also incubated with Alexafluor 568-conjugated phalloidin (red) to visualize F-actin distribution. Surfacic reconstructions were realized from L1210 cells treated with or without etxfag (right and left row, respectively). Upper panels represent $\mathrm{P}(861)$ fak labelling, middle panels represent $\mathrm{P}(861)$ fak $+\mathrm{F}-\mathrm{actin}$ labelling and bottom panels represent colocalization between $\mathrm{P}(861)$ fak and $\mathrm{F}$-actin (gold). A representative image of three independent experiments is shown. 
a

IB (whole cell extracts)


c wo Etxfag
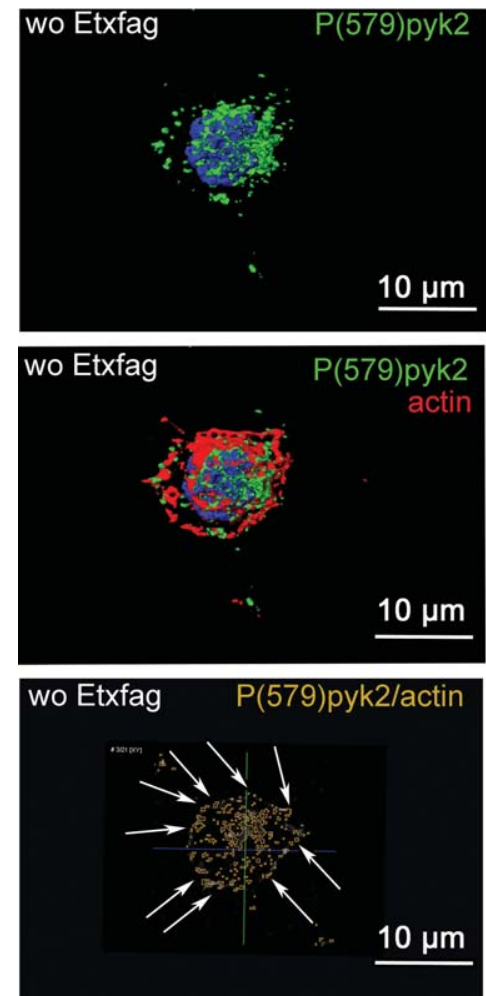

b

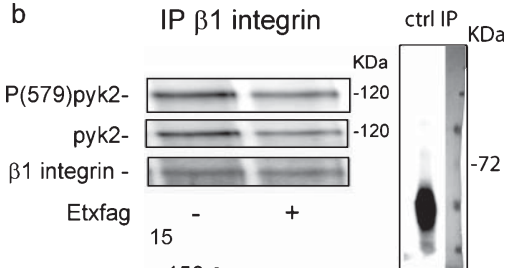

150

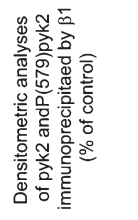

pyk2 P-pyk2/pyk2

100

50

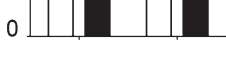

Etxfag
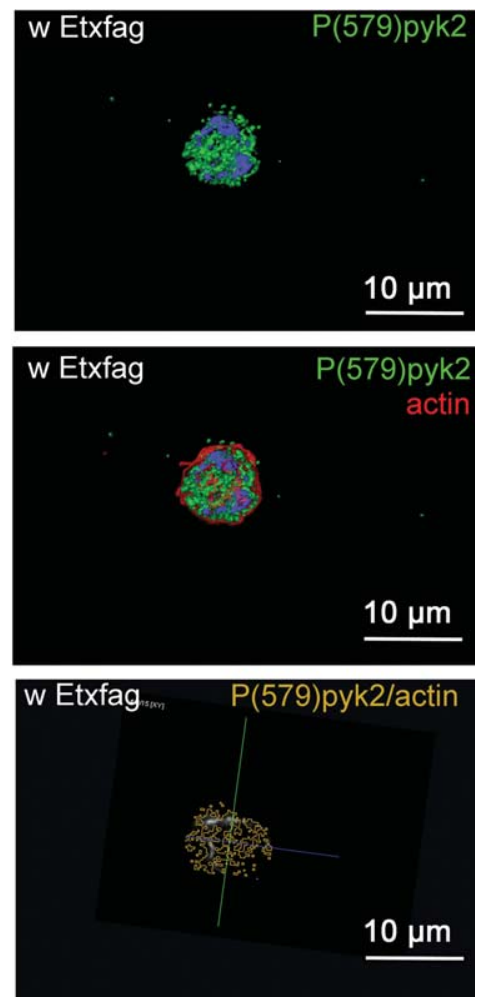

Fig. 6. Etxfag prevents pyk2 phosphorylation and association with $\beta 1$ integrin. a) Whole cell lysates prepared from L1210 cells treated or not with $1 \times 10^{-7} \mathrm{M}$ Etxfag during $24 \mathrm{~h}$ were subjected to immunoblotting with anti-phosphorylated-Y579-pyk2 and pyk2. A representative blot of three independent experiments was shown. Graph represents the densitometric analysis of the ratio $\mathrm{P}(579)$ pyk $2 /$ pyk2 in control ( $\square)$ and treated (ם) cells. ${ }^{*} P<0.05$. b) Cell lysates prepared from L1210 cells treated or not with $1 \times 10^{-7} \mathrm{M}$ etxfag during $24 \mathrm{~h}$ were immunoprecipitated with anti- $\beta 1$ antibody and immunoblotted with anti-phosphorylated-Y579-pyk2 and pyk2. Non specific IgGs were used as negative controls of immunoprecipitation (windows). A representative blot of three independent experiments was shown. Graph represents the densitometric analysis of the ratio $\mathrm{P}(579)$ pyk2/pyk2 in control $(\square)$ and treated $(\square)$ cells. $* P<0.05$. c) L1210 cells treated or not with $1 \times 10^{-7} \mathrm{M}$ etxfag for $24 \mathrm{~h}$ were seeded to FN/V for $2 \mathrm{~h}$. Cells were fixed with paraformaldehyde $4 \%$ and permeabilized with $0.1 \%$ Triton X-100. Cells were labelled with anti-phosphorylated-Y579-pyk2 and then with a secondary antibody linked to Alexafluor 488 (green). Cells were also incubated with Alexafluor 568-conjugated phalloidin (red) to visualize F-actin distribution. Blue color represents nuclear staining with DAPI. Surfacic reconstructions were realized from L1210 cells treated with (right row) or without etxfag (left row). Upper panels represent $\mathrm{P}(579)$ pyk2 labelling, middle panels represent $\mathrm{P}(579)$ pyk2 + F-actin labelling and bottom panels represent colocalization between $\mathrm{P}(579)$ pyk2 and F-actin (gold). A representative image of three independent experiments is shown. 

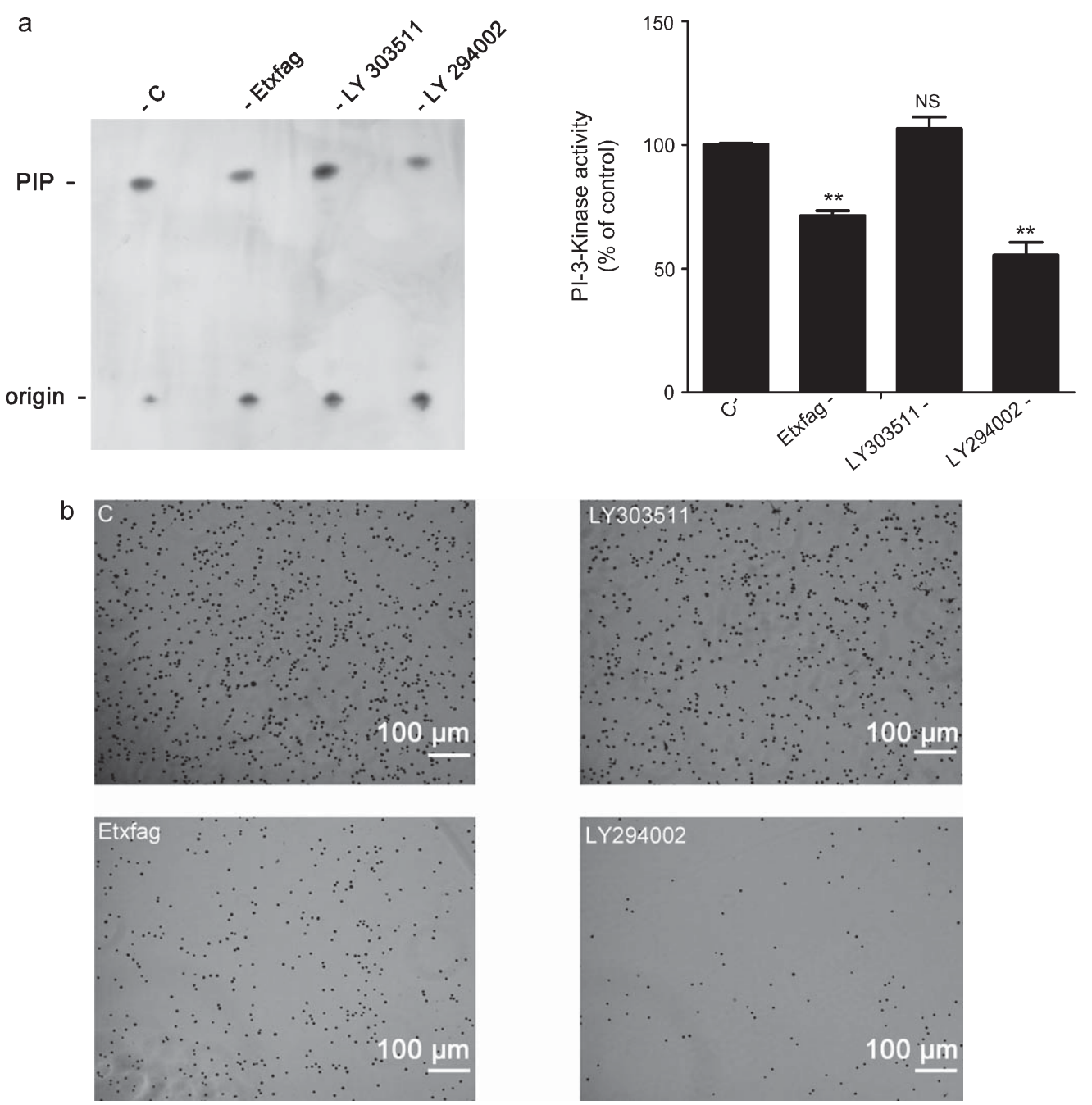

Fig. 7. Etxfag decreased PI-3 kinase activity in FN/V-adhered L1210 cells. a) L1210 cells treated or not with $1 \times 10^{-7} \mathrm{M}$ etxfag for $24 \mathrm{~h}$ were seeded to FN/V for $2 \mathrm{~h}$ in a serum-free medium. Adherent cells were incubated with $25 \mu \mathrm{M}$ LY294002 or $25 \mu \mathrm{M}$ LY303511 for 30 min before lysed. Anti-p85 immunoprecipitates were subjected to PI 3-kinase activity determined by PI phosphorylation in the presence of $\left[\gamma^{-}{ }^{32} \mathrm{P}\right]$ ATP. Phosphorylated PI (PIP) was separated by TLC and analysed by autoradiography. Quantification of PI phosphorylation was expressed as the percentage of signal obtained in FN/V-adhered cells. Results are representative of two independent experiments and values are the means \pm SD. $* * P<0.01$ compared with control FN/V-adhered cells. NS = non significative. b) L1210 cells treated or not with either $1 \times 10^{-7} \mathrm{M}$ etxfag for $24 \mathrm{~h}$ or $25 \mu \mathrm{M}$ LY294002 or $25 \mu \mathrm{M}$ LY303511 for $30 \mathrm{~min}$ were seeded to FN/V for $2 \mathrm{~h}$. Non-adherent cells were discarded and adherent cells stained by violet crystal were visualized by microscopy.

\section{Discussion}

Progression of acute leukemias is depicted by excessive egress of leukemic blasts and cell infiltration in multiple organs through a series of processes including cell adhesion and ECM proteolysis. Adhesive interactions with the ECM proteins play a crucial role in the homing of normal hematopoietic cells within the bone marrow but can also facilitate leukemic cell lodgment leading to the persistence of residual disease [26]. These interactions can also protect leukemic cells from chemotherapy-induced apoptosis [27]. New anti-leukemic therapeutics targeting cell interactions with the BM could be used in combination with conventional cytotoxic drugs to eradicate leukemic cells. Fagaronine zanthoxylum $L$ is a benzo[c]phenanthridine described for its anti-leukemic capacity linked to DNA topoisomerase inhibition [28-30]. Its 



Fig. 8. Lipid raft integrity is necessary for L1210 cell adhesion to FN/V peptide. a) L1210 cells treated or not with $10 \mathrm{mM} \mathrm{M} \beta C D$ for $1 \mathrm{~h}$ were seeded to FN/V-coated glass culture slides in serum-free medium for $2 \mathrm{~h}$. Blue color represents nuclear staining with DAPI. L1210 cells were fixed with $4 \%$ paraformaldehyde then incubated with Alexa Flour 488-conjugated CTxB (green). $Z$ projection $(Z=0.25 \mu \mathrm{m})$ were realized by confocal microscopy using adequate settings for each fluorophore. Images were analysed with Amira ${ }^{\mathrm{TM}}$ and are representative of three independent experiments (upper panels). L1210 cells treated or not with $10 \mathrm{mM} \mathrm{M \beta CD}$ for $1 \mathrm{~h}$ were seeded to FN/V for $2 \mathrm{~h}$ in a serum-free medium. Non-adherent cells were then discarded and adherent cells stained by violet crystal were visualized by microscopy (bottom panel). b) L1210 cells treated or not with $1 \times 10^{-7} \mathrm{M}$ etxfag during $24 \mathrm{~h}$ were seeded onto FN/V-coated glass culture slides in serum-free medium for $2 \mathrm{~h}$. Cells were fixed with $4 \%$ paraformaldehyde then incubated with a primary anti- $\beta 1$ antibody $(1: 100)$ and labelled with a secondary antibody linked to Alexafluor 568 (data not shown). Cells were also incubated with Alexafluor 488-conjugated cholera toxin subunit B (CTxB). Blue color represents nuclear staining with DAPI. Surfacic reconstructions were realized from L1210 cells treated with (bottom panels) or without etxfag (upper panels). Surfacic reconstruction were proceeded from GM1 labelling (left row, upper and bottom panels) and from colocalization between GM1 and $\beta 1$ (right row, upper and bottom panel) (gold). A representative image of three independent experiments is shown. c) L1210 cells were treated or not with $1 \times 10^{-7} \mathrm{M}$ Etxfag during $24 \mathrm{~h}$ then subjected to lipid extraction. GM1 ganglioside was used as a marker of lipid raft and its expression was assessed by using dot-blot CTxB staining followed by fluorescence spectroscopy analysis. 


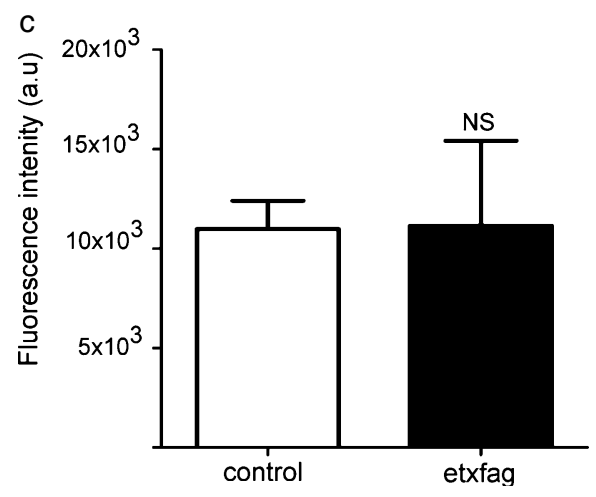

Fig. 8. (continued)

high toxicity and insolubility in biological fluids render fagaronine unusable in vivo [31]. In order to improve the anti-leukemic potency while reducing the toxicity of benzo[c]-phenanthridines, derivatives of fagaronine like ethoxfagaronine (etxfag) have been synthesized $[20,32]$. Etxfag exhibits higher solubility in aqueous solvents and we recently reported that it reduced murine leukemic L1210 cell invasiveness [22].

In order to gain insight into the mechanism of action of etxfag as an anti-leukemic agent, our present study explored the effect of etxfag treatment on cell adhesion to FN, one of the major components of the bone marrow microenvironment. We showed that subtoxic concentration of etxfag modulated $\beta 1$ integrin-dependent adhesion of L1210 cells to FN and that this effect was associated with an inhibition of $\beta 1$ clustering leading to a decrease of focal adhesion complexes.

Interaction of leukemic cell with $\mathrm{FN}$ on stromal cells controls minimal residual disease and involves $\alpha 4 \beta 1$ [26]. The value of $\alpha 4 \beta 1$ as a prognostic marker is controversial as its expression is associated with a high initial blast cell count but not with AML evolution thus suggesting that targeting $\beta 1$ integrin may not be an efficient strategy [33]. This is reinforced by studies reporting that $\beta 1$ integrin-dependent adhesion up-regulate MMPs [34]. Integrins act as bidirectional transducers that connect ECM proteins with the cytoskeleton through focal adhesion sites recruiting scaffolding proteins. Within these sites, fak is the key kinase initiating $\beta 1$ integrin signaling pathway. Fak is aberrantly regulated in acute leukemic cells and its expression correlates with enhanced cell migration and drug resistance in vitro [12]. Pyk2, another focal adhesion tyrosine kinase, can replace fak in integrinmediated signaling events and its overexpression is often associated with enhanced metastasis [35]. Fak and pyk 2 could thereby represent new molecular therapeutic targets for leukemia but these two kinases can be regulated differently in response to the same stimulus while sharing some functions $[36,37]$. The ability of pyk2 to compensate fak deficiency suggests that targeting pyk 2 might be a better therapeutic approach in leukemia.

Our data indicate that fak and pyk2 are phosphorylated on tyrosine 576, 861 and 579 and associated with $\beta 1$ integrin in FN-adhered L1210 cells. Interestingly, phosphorylated fak and pyk2 were localized at the cell periphery as well as in actin-rich extensions of L1210 cells thus confirming their role in cell spreading and migration. Etxfag affected all these phosphorylation sites as well as pyk2 recruitment to $\beta 1$ integrin. In the focal adhesion complex, pyk2 phosphorylation induces PI 3-kinase recruitment and its subsequent activation. Activated PI 3-kinase phosphorylates pyk2 which binds to $\beta 1$ integrin cytoplasmic tail [35]. Our data show that PI 3-kinase activity was enhanced in FNadhered L1210 cells and partially reduced by etxfag. The fact that etxfag inhibits PI 3-kinase might thus explain prevention of pyk 2 recruitment to $\beta 1$ integrin and points the inhibitory activity of etxfag on $\beta 1$ integrin signaling cascade.

Integrin signaling is controlled by several mechanisms including receptor clustering. Large lipid rafts are necessary to create a new microenvironment where focal adhesion proteins are phosphorylated thus modulating downstream signaling and integrin partitioning in lipid rafts [38]. In FN-attached L1210 cells, lipid rafts appeared as large patches and colocalized with $\beta 1$ integrin. Cholesterol depletion impaired L1210 cell adhesion indicating that lipid raft integrity was required for this process. Treatment with etxfag induced a relocalization of lipid rafts without impacting the cellular distribution of $\beta 1$ integrin. Modification of the membrane microenvironment could explain the loss of $\beta 1$ integrin adherence properties. As a consequence, the inhibition of lipid raft clustering by etxfag might constitute the major event leading to the suppression of integrin clustering, focal adhesion contact formation and ultimately cell adhesion to FN.

In conclusion, our results depicted that etxfag displays a significant inhibitory effect on L1210 cell adhesion and spreading through the inhibition of $\beta 1$ integrin signaling cascade. The observed effects have been also confirmed in two human acute leukemia cell lines (supplementary Figure 3), SHI-1 (established 
from mononuclear cells isolated from the bone marrow of a patient with AML at relapse) and NALM-6 (established from B cell precursors from the peripheral blood of a patient with ALL at relapse). By targeting several processes responsible for leukemic cell development i.e. cell dissemination and adhesion to bone marrow proteins, etxfag appears as a new potential anti-leukemic agent and further preclinical studies may provide the basis for the development of more effective anti-leukemic treatments.

\section{Acknowledgments}

This work was supported by grants from CNRS and Ligue Contre le Cancer Comité de la Haute-Marne. We would like to thank Dr Laetitia Devy for her advices. We would like to thank Dr Hassan El Btaouri for his help concerning GM1 studies. We would like to thank Amélie Hatte for her technical assistance. This manuscript is dedicated to the memory of Dr Enguerran Vanquelef.


Supplementary Figure 1. Etxfag prevents vinculin association with fak in L1210 cells. L1210 cells treated or not with $1 \times 10^{-7} \mathrm{M}$ etxfag during $24 \mathrm{~h}$ were seeded to FN/V-coated glass culture slides in serum-free medium for $2 \mathrm{~h}$. Cells were fixed with $4 \%$ paraformaldehyde then incubated with anti-fak primary antibody $(1: 100)$ and labelled with secondary antibody linked to Alexafluor 488 (green). Cells were also incubated with anti-vinculin primary antibody $(1: 100)$ and labelled with secondary antibody linked to Alexafluor 568-(red).

Emitted fluorescence was detected through the appropriate wavelength window. Twenty images were captured with a $0.25 \mu \mathrm{m}$ z-step. Surfacic reconstructions were realized from L1210 cells treated with (right row) or without etxfag (left row). Differential interferential contrast imaging of L1210 cells treated or not by etxfag was proceeded (right and left row, upper panel). Upper panels represent fak labelling (green), middle panels represent vinculin labelling (red) and bottom panels represent colocalization between fak and vinculin (gold). A representative image of three independent experiments was shown. Scale bar: $10 \mu \mathrm{m}$. 
a
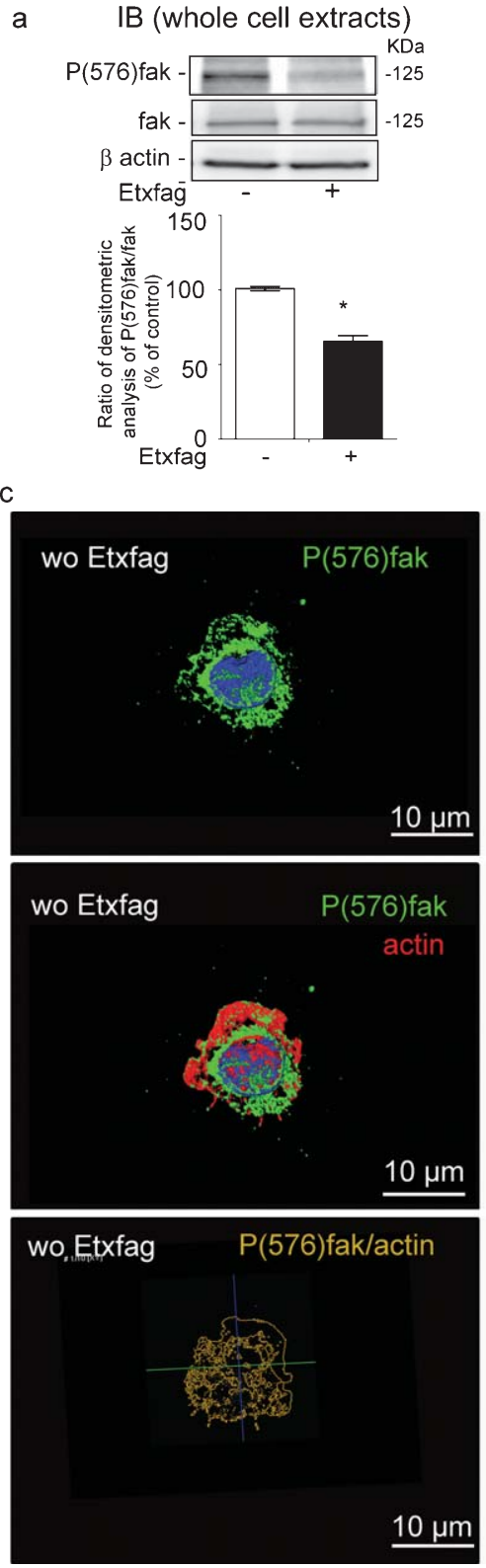

b IP ( $\beta 1$ integrin)
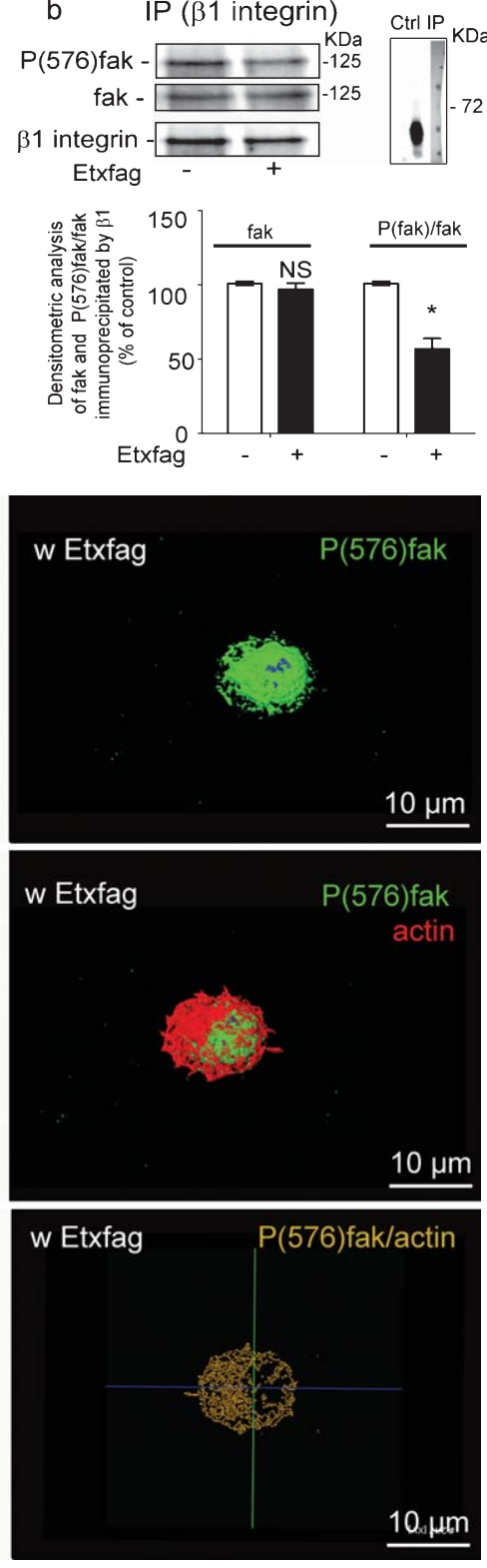

Supplementary Figure 2. Etxfag prevents fak phosphorylation on Tyr 576. a) Whole cell lysates prepared from L1210 cells treated or not with $1 \times 10^{-7} \mathrm{M}$ etxfag during $24 \mathrm{~h}$ were subjected to immunoblotting with antibodies anti-phosphorylated-Y576 fak and fak. A representative blot of three independent experiments is shown. Graph represents the densitometric analysis of the ratio $\mathrm{P}(576)$ fak/fak in control ( $\square$ ) and treated (ם) cells. $* P<0.05$. b) Cell lysates prepared from L1210 cells treated or not with $1 \times 10^{-7} \mathrm{M}$ etxfag during $24 \mathrm{~h}$ were immunoprecipitated with anti- $\beta 1$ antibody and immunoblotted with antibodies anti-phosphorylated-Y576-fak and fak. Non specific IgGs were used as negative controls of immunoprecipitation (windows). A representative blot of three independent experiments was shown. Graph represents the densitometric analysis of the ratio $\mathrm{P}(576)$ fak/fak in control $(\square)$ and treated $(\mathbf{\square})$ cells. ${ }^{*} P<0.05$. c) L1210 cells treated or not with $1 \times 10^{-7} \mathrm{M}$ etxfag for $24 \mathrm{~h}$ were seeded to FN/V for $2 \mathrm{~h}$. Cells were fixed with paraformaldehyde $4 \%$ and permeabilized with $0.1 \%$ Triton X-100. Blue color represents nuclear staining with DAPI. Cells were labelled with antibodies anti-phosphorylated-Y576-fak and then with a secondary antibody linked to Alexafluor 488 (green). Cells were also incubated with Alexafluor 568-conjugated phalloidin (red) to visualize F-actin distribution. Surfacic reconstructions were realized from L1210 cells treated with (right row) or without etxfag (left row). Upper panels represent P(576)fak labelling, middle panels represent $\mathrm{P}(576) \mathrm{fak}+\mathrm{F}$-actin labelling and bottom panels represent colocalization between $\mathrm{P}(576)$ fak and F-actin (gold). A representative image of three independent experiments is shown. 

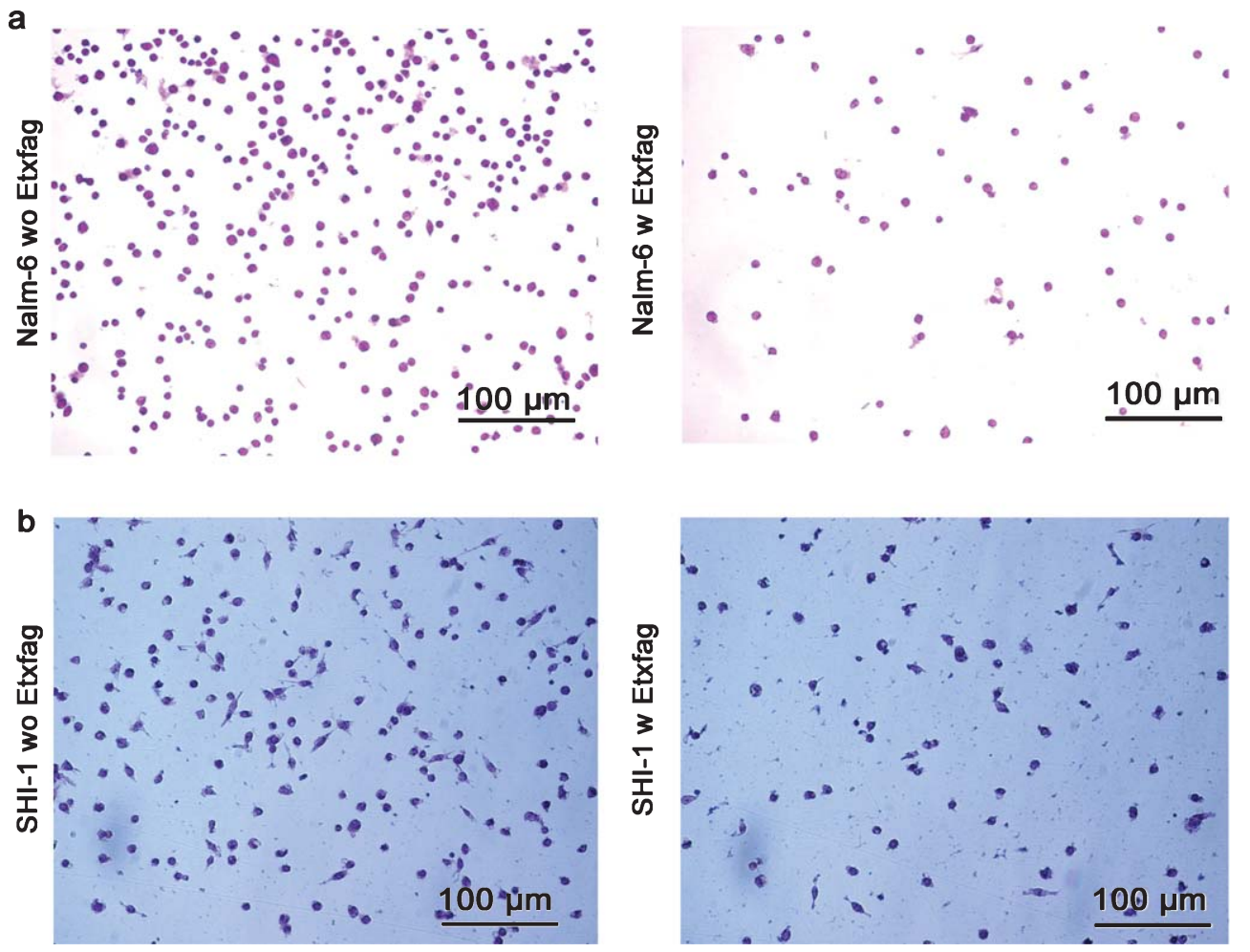

Supplementary Figure 3. Etxfag inhibits Nalm- 6 and SHI- 1 cell adhesion to FN/V peptide. a) $25 \times 10^{4}$ Nalm- 6 cells treated or not with $1 \times 10^{-7} \mathrm{M}$ etxfag for $24 \mathrm{~h}$ were seeded on FN/V peptide $\left(5 \mu \mathrm{g} / \mathrm{cm}^{2}\right)$ for $2 \mathrm{~h}$ in serum free condition. Non-adherent cells were then discarded and adherent cells stained by violet crystal were visualized by microscopy. b) $25 \times 10^{4} \mathrm{SHI}-1$ cells treated or not with $1 \times 10^{-7} \mathrm{M}$ etxfag for $24 \mathrm{~h}$ were seeded on FN/V peptide $\left(5 \mu \mathrm{g} / \mathrm{cm}^{2}\right)$ for $2 \mathrm{~h}$ in serum free condition. Non-adherent cells were then discarded and adherent cells stained by violet crystal were visualized by microscopy. (Colours are visible in the online version of the article; http://dx.doi.org/10.3233/ACP-2012-0055)

\section{References}

[1] R.K. Narla, Y. Dong, D. Klis and F.M. Uckun, Bis(4,7dimethyl-1,10-phenanthroline) sulfatooxovanadium(I.V.) as a novel antileukemic agent with matrix metalloproteinase inhibitory activity, Clin Cancer Res 7 (2001), 1094-1101.

[2] C. Wang, Z. Chen, Z. Li and J. Cen, The essential roles of matrix metalloproteinase-2, membrane type 1 metalloproteinase and tissue inhibitor of metalloproteinase- 2 in the invasive capacity of acute monocytic leukemia SHI-1 cells, Leuk Res 34 (2010), 1083-1090.

[3] A. Suminoe, A. Matsuzaki, H. Hattori, Y. Koga, E. Ishii and T. Hara, Expression of matrix metalloproteinase (MMP) and tissue inhibitor of MMP (TIMP) genes in blasts of infant acute lymphoblastic leukemia with organ involvement, Leuk Res $\mathbf{3 1}$ (2007), 1437-1440.

[4] J.H. Song, S.H. Kim, D. Cho, I.K. Lee, H.J. Kim and T.S. Kim, Enhanced invasiveness of drug-resistant acute myeloid leukemia cells through increased expression of matrix metalloproteinase-2, Int J Cancer 125 (2009), 1074-1081.

[5] P.S. Becker, K.J. Kopecky, A.N. Wilks, S. Chien, J.M. Harlan, C.L. Willman, S.H. Petersdorf, D.L. Stirewalt, T. Papayannopoulou and F.R. Appelbaum, Very late antigen-4 function of myeloblasts correlates with improved overall sur- vival for patients with acute myeloid leukemia, Blood 113 (2009), 866-874.

[6] R.O. Hynes, Integrins: Versatility, modulation, and signaling in cell adhesion, Cell 69 (1992), 11-25.

[7] M. Delforge, V. Raets, V. Van Duppen, P. Vandenberghe and M. Boogaerts, CD34+ marrow progenitors from MDS patients with high levels of intramedullary apoptosis have reduced expression of alpha4beta1 and alpha5beta 1 integrins, Leukemia 19 (2005), 57-63.

[8] M. Takahashi, S. Hamano, H. Takahashi and A. Okano, In vitro attachment of bovine hatched blastocysts on fibronectin is mediated by integrin in a RGD dependent manner, J Reprod Dev 51 (2005), 47-57.

[9] A. Sharma, J.A. Askari, M.J. Humphries, E.Y. Jones and D.I. Stuart, Crystal structure of a heparin- and integrin-binding segment of human fibronectin, EMBO J 18 (1999), 1468-1479.

[10] T.A. Springer and J.H. Wang, The three-dimensional structure of integrins and their ligands, and conformational regulation of cell adhesion, Adv Protein Chem 68 (2004), 29-63.

[11] Y. Imai, M. Shimaoka and M. Kurokawa, Essential roles of VLA-4 in the hematopoietic system, Int J Hematol 91 (2010), 569-575.

[12] C. Recher, L. Ysebaert, O. Beyne-Rauzy, V. Mansat-De Mas, J.B. Ruidavets, P. Cariven, C. Demur, B. Payrastre, G. Laurent 
and C. Racaud-Sultan, Expression of focal adhesion kinase in acute myeloid leukemia is associated with enhanced blast migration, increased cellularity, and poor prognosis, Cancer Res 64 (2004), 3191-3197.

[13] S. Sarkar, M. Svoboda, R. de Beaumont and A.S. Freedman, The role of Aktand RAFTK in betal integrin mediated survival of precursor B-acute lymphoblastic leukemia cells, Leuk Lymphoma 43 (2002), 1663-1671.

[14] E. Wunder, H. Sovalat, H. Liang, M. Becker and P. Henon, Impact of the degree of maturation and differentiation of CD34+ cells in grafts of different origin on the duration of aplasia, Prog Clin Biol Res 389 (1994), 345-350.

[15] I. Ivankovic-Dikic, E. Gronroos, A. Blaukat, B.U. Barth and I. Dikic, Pyk2 and FAK regulate neurite outgrowth induced by growth factors and integrins, Nat Cell Biol 2 (2000), 574-581.

[16] C.K. Sun, K.T. Ng, B.S. Sun, J.W. Ho, T.K. Lee, I. Ng, R.T. Poon, C.M. Lo, C.L. Liu, K. Man and S.T. Fan, The significance of proline-rich tyrosine kinase2 (Pyk2) on hepatocellular carcinoma progression and recurrence, Br J Cancer 97 (2007), 50-57.

[17] S. Avraham and H. Avraham, Characterization of the novel focal adhesion kinase RAFTK in hematopoietic cells, Leuk Lymphoma 27 (1997), 247-256.

[18] C.A. Lipinski and J.C. Loftus, Targeting Pyk2 for therapeutic intervention, Expert Opin Ther Targets 14 (2010), 95-108.

[19] A. Philchenkov, V. Kaminskyy, M. Zavelevich and R. Stoika, Apoptogenic activity of two benzophenanthridine alkaloids from Chelidonium majus L. does not correlate with their DNA damaging effects, Toxicol In Vitro 22 (2008), 287-295.

[20] M.A. Lynch, O. Duval, A. Sukhanova, J. Devy, S.P. MacKay, R.D. Waigh and I. Nabiev, Synthesis, biological activity and comparative analysis of DNA binding affinities and human DNA topoisomerase I inhibitory activities of novel 12-alkoxybenzo[c]phenanthridinium salts, Bioorg Med Chem Lett 11 (2001), 2643-2646.

[21] A. Deroussent, M. Re, H. Hoellinger, E. Vanquelef, O. Duval, M. Sonnier and T. Cresteil, In vitro metabolism of ethoxidine by human CYP1A1 and rat microsomes: Identification of metabolites by high-performance liquid chromatography combined with electrospray tandem mass spectrometry and accurate mass measurements by time-of-flight mass spectrometry, Rapid Commun Mass Spectrom 18 (2004), 474-482.

[22] J. Devy, F. Ouchani, C. Oudot, J.J. Helesbeux, E. Vanquelef, S. Salesse, F. Rabenoelina, S. Al-Khara, I. Letinois, O. Duval, L. Martiny and E. Charpentier, The anti-invasive activity of synthetic alkaloid ethoxyfagaronine on L1210 leukemia cells is mediated by down-regulation of plasminogen activators and MT1-MMP expression and activity, Invest New Drugs 29(5) (2010), 730-741.

[23] R.J. Gillies, N. Didier and M. Denton, Determination of cell number in monolayer cultures, Anal Biochem 159 (1986), 109-113.

[24] E. Lambert, C. Boudot, Z. Kadri, M. Soula-Rothhut, M.L. Sowa, P. Mayeux, W. Hornebeck, B. Haye and E. Petitfrere, Tissue inhibitor of metalloproteinases-1 signalling pathway leading to erythroid cell survival, Biochem J 372 (2003), 767-774.

[25] A.S. Kristof, G. Pacheco-Rodriguez, B. Schremmer and J. Moss, LY303511 (2-piperazinyl-8-phenyl-4H-1-benzopyran- 4-one) acts via phosphatidylinositol 3-kinase-independent pathways to inhibit cell proliferation via mammalian target of rapamycin (mTOR)- and non-mTOR-dependent mechanisms J Pharmacol Exp Ther 314 (2005), 1134-1143.

[26] T. Matsunaga, N. Takemoto, T. Sato, R. Takimoto, I. Tanaka, A. Fujimi, T. Akiyama, H. Kuroda, Y. Kawano, M. Kobune, J. Kato, Y. Hirayama, S. Sakamaki, K. Kohda, K. Miyake and Y. Niitsu, Interaction between leukemic-cell VLA-4 and stromal fibronectin is a decisive factor for minimal residual disease of acute myelogenous leukemia, Nat Med 9 (2003), 1158-1165.

[27] R.E. Mudry, J.E. Fortney, T. York, B.M. Hall and L.F. Gibson, Stromal cells regulate survival of B-lineage leukemic cells during chemotherapy, Blood 96 (2000), 1926-1932.

[28] A.K. Larsen, L. Grondard, J. Couprie, B. Desoize, L. Comoe, J.C. Jardillier and J.F. Riou, The antileukemic alkaloid fagaronine is an inhibitor of DNA topoisomerases I and II, Biochem Pharmacol 46 (1993), 1403-1412.

[29] L. Comoe, P. Jeannesson, C. Trentesaux, B. Desoize and J.C. Jardillier, The antileukemic alkaloid fagaronine and the human K 562 leukemic cells: Effects on growth and induction of erythroid differentiation, Leuk Res 11 (1987), 445-451.

[30] W.M. Messmer, M. Tin-Wa, H.H. Fong, C. Bevelle, N.R. Farnsworth, D.J. Abraham and J. Trojanek, Fagaronine, a new tumor inhibitor isolated from Fagara zanthoxyloides Lam. (Rutaceae), J Pharm Sci 61 (1972), 1858-1859.

[31] T. Nakanishi, M. Suzuki, A. Saimoto and T. Kabasawa, Structural considerations of NK109, an antitumor benzo[c]phenanthridine alkaloid, J Nat Prod 62 (1999), 864-867.

[32] E. Vanquelef, J.J. Helesbeux, O. Duval, E. Debiton, C. Barthomeuf, C. Jarry, I. Forfar and P. Richomme, Richomme, Synthesis and PC3 androgen-independent prostate cells antiproliferative effect of fagaronine derivatives, $J$ Enzyme Inhib Med Chem 22 (2007), 647-654.

[33] L. Vila, X. Thomas, L. Campos, O. Sabido and E. Archimbaud, Expression of VLA molecules on acute leukemia cells: Relationship with disease characteristics, Exp Hematol 23 (1995), 514-518.

[34] A. Dutta, T. Sen and A. Chatterjee, Culture of K562 human myeloid leukemia cells in presence of fibronectin expresses and secretes MMP-9 in serum-free culture medium, Int J Clin Exp Pathol 3 (2010), 288-302.

[35] S. Melikova, S.J. Dylla and C.M. Verfaillie, Phosphatidylinositol-3-kinase activation mediates prolinerich tyrosine kinase 2 phosphorylation and recruitment to beta1-integrins in human CD34+ cells, Exp Hematol 32 (2004), 1051-1056.

[36] J.W. Tyner, D.K. Walters, S.G. Willis, M. Luttropp, J. Oost, M. Loriaux, H. Erickson, A.S. Corbin, T. O'Hare, M.C. Heinrich, M.W. Deininger and B.J. Druker, RNAi screening of the tyrosine kinome identifies therapeutic targets in acute myeloid leukemia, Blood 111 (2008), 2238-2245.

[37] Y. Le, L. Xu, J. Lu, J. Fang, V. Nardi, L. Chai and L.E. Silberstein, FAK silencing inhibits leukemogenesis in BCR/ABL-transformed hematopoietic cells, Am J Hematol 84 (2009), 273-278.

[38] C. Wang, Y. Yoo, H. Fan, E. Kim, K.L. Guan and J.L. Guan, Regulation of Integrin beta 1 recycling to lipid rafts by Rab1a to promote cell migration, J Biol Chem 285 (2010), 29398-29405. 


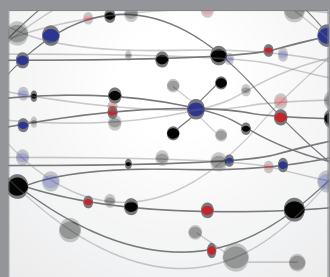

The Scientific World Journal
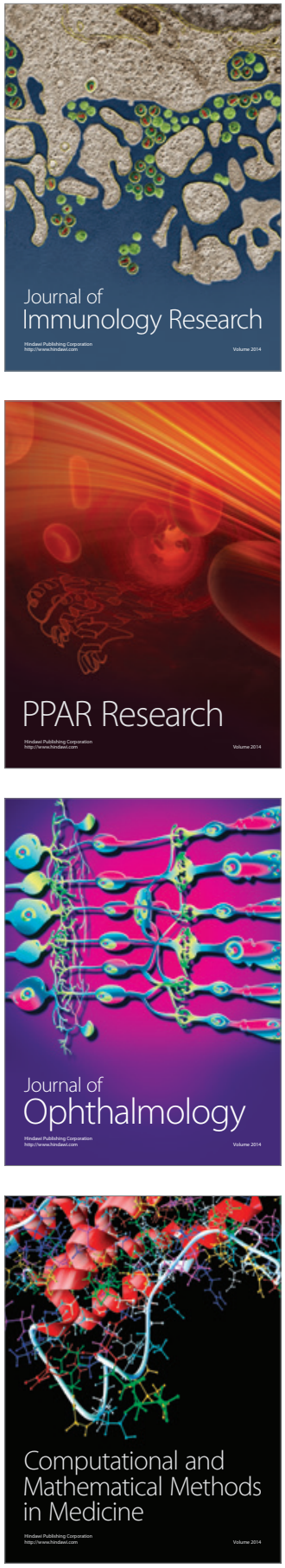

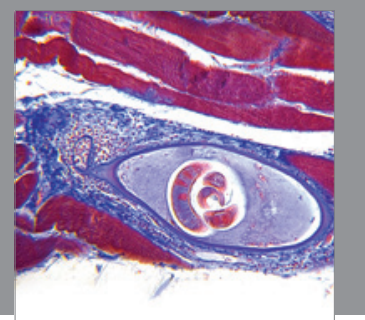

Gastroenterology

Research and Practice
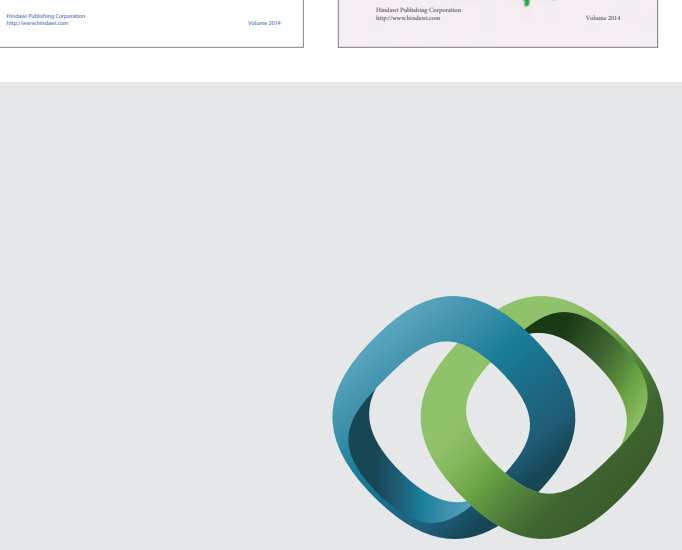

\section{Hindawi}

Submit your manuscripts at

http://www.hindawi.com
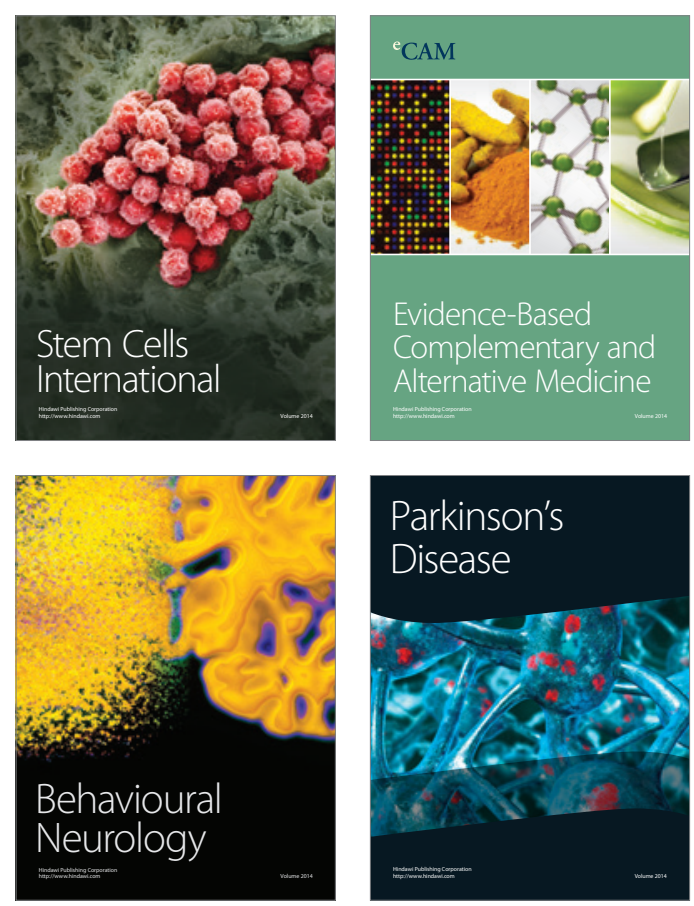

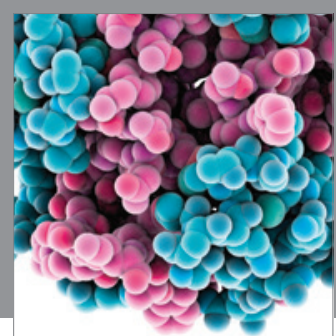

Journal of
Diabetes Research

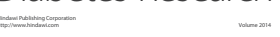

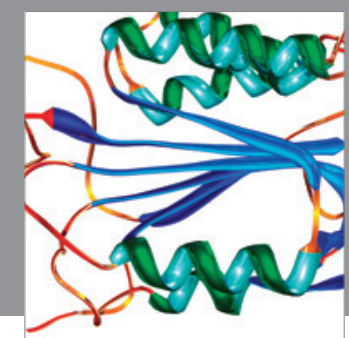

Disease Markers
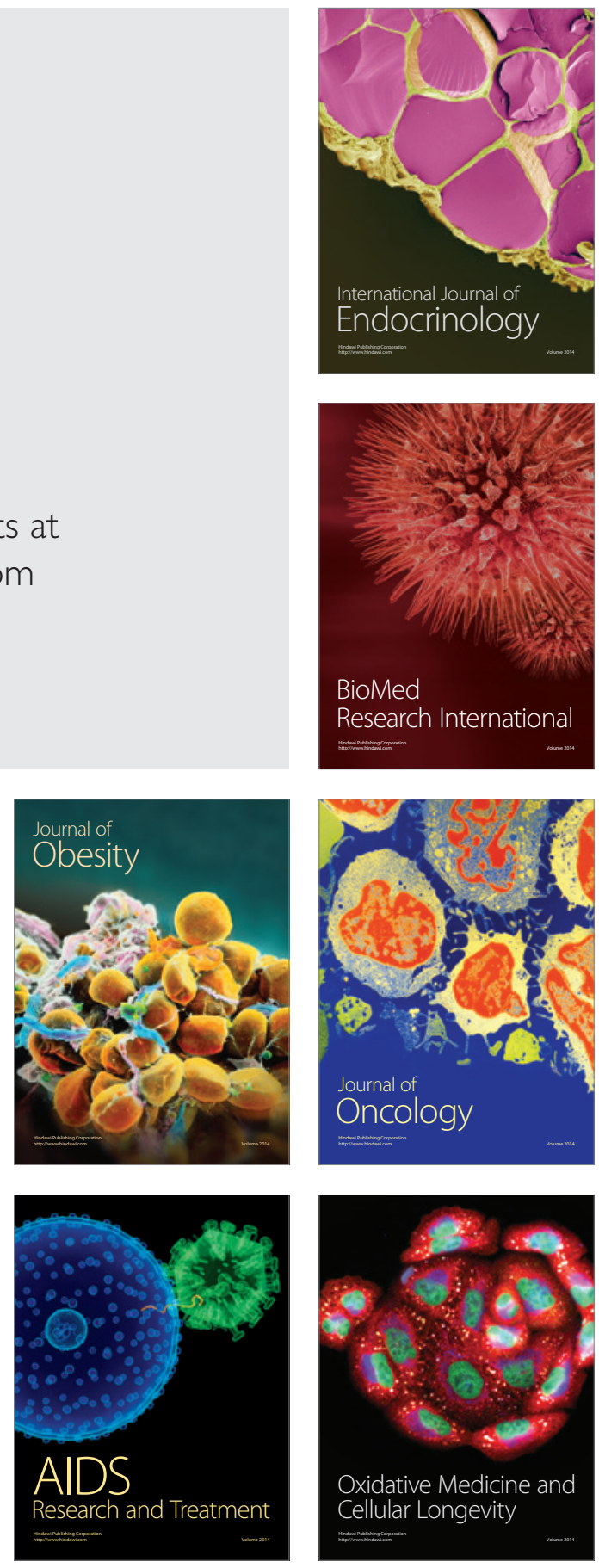